\title{
Delignification Process of Agro-Industrial Wastes an Alternative to Obtain Fermentable Carbohydrates for Producing Fuel
}

\author{
Oscar Sánchez ${ }^{1}$, Roció Sierra ${ }^{1}$ and Carlos J. Alméciga-Díaz ${ }^{2}$ \\ 1 Universidad de Los Andes, Chemical Engineering Department \\ 2 Pontificia Universidad Javeriana \\ Institute for the Study of Inborn Errors of Metabolism,Bogotá
}

Colombia

\section{Introduction}

Fossil fuels, mainly petroleum, coal, and natural gas, were the main energy sources for most industries during the 20th century, and are still the most important feedstocks to produce energy in the world. "Currently, the world energy market worth around 1.5 trillion dollars is dominated by fossil fuels" (Goldemberg, 2006). However, these sources are not longer regarded sustainable, and their availability is much lower. Shafiee and Topal (2009) predicted that oil, coal and gas reserves will last around 35, 107 and 37 years for petroleum, coal and natural gas, respectively. In addition their combustion involve environmental issues such as global warming due to greenhouse gas emissions (Naik et al., 2010). Therefore, the interest for questing sustainable and environmental energy sources has risen in the last two decades; giving origin to the production of fuels from renewable feedstocks, such as biomass. These feedstocks are commonly divided in three categories: wood, residues from agricultural, industrial or domestic origin, and energy crops from dedicated farming (Bringezu et al., 2007).

The use of these renewable resources to produce fuel has created two different generations in biofuel production. The first biofuel generation is based on grain or food sources, and is constituted mainly by ethanol, fatty acid methyl ester (FAME), and pure plant oil (PPO) (Bringezu et al., 2007). However, environmental impacts, energy efficiency, and eutrophycation have limited the production of these first generation biofuels. In addition, land competition of energy crops with food crops has arisen a fuel-versus-food debate exacerbated by the increase of food prices, particularly those of maize, wheat, sugar beet, cassava, sweet sorghum, sugarcane, oilseed rape, soybean and oil palm (Börjesson \& Tufvesson, 2011; Vries et al., 2010). For example, the United States Department of Energy reported that in 2005 the bioethanol production reached about 15 billion litters for which nearly $36 \mathrm{MMt}$ of maize, $13 \%$ of total US maize crops, were used. These values were estimated to double in 2010 by the Renewable Fuel Association (Cassman \& Liska, 2007).

The second generation of biofuels is produced from non-grain and non-food sources such as lignocellulosic sources and algae biomass (Naik et al., 2010; Simmons et al., 2008). 
Lignocellulosic feedstocks include agro-industrial by-products, perennial grasses, vegetable and wood residues. They can be burned to produce heat and electricity and also be used to obtain liquid fuels (Naik et al., 2010). Wastes and by-products from agro-industrial processes such as coconut shells, rice husks, sugarcane bagasse, corncob and corn stover among many others, are abundantly produced in the world daily and have modest if any applications. These wastes and by-products are rich sources of cellulose and hemicellulose, which constitute important substrates in fermentative processes directed to biofuel production. However, as opposed to sugarcane juice or maize starch, these substrates are not readily available. The structural carbohydrates in the plant cell wall are wrapped up in lignin, which is an inert polymer that protects the plant and consequently constitutes an important barrier to fermentation. Therefore, a very effective way - but not the only option - to significantly increase biomass digestibility is lignin degradation or separation (delignification). The operation is aimed to increase the digestibility of constituent sugars through increment in gross material pore size (Sierra et al., 2008). It is challenging due to the recalcitrance of lignin and may require expensive chemicals and relatively high temperatures and pressures for acceptable reaction rates. Otherwise, at mild conditions (i.e. use of microorganisms or purified enzymes) it takes long times. Other ways to increase lignocelluloses digestibility include partial to total solubilization of hemicelluloses, and separation acetyl groups that link hemicellulose and lignin (Zhu et al., 2008). Crystallinity reduction of cellulose fibrils is sought because low crystallinity results in more reactivity; however, after delignification and sugar degradation with chemicals, an increased crystallinity is usually observed (Chang \& Holtzapple, 2000). This increase is attributed to a preferential degradation of amorphous cellulose and less ordered crystalline forms during chemical pretreatment. A common method to obtain a significant reduction in crystallinity is sudden release of reactor vapor pressure. This operation is known as steam explosion.

The operations aimed to turn lignocellulose digestible through either of the mechanisms described above are widely known as "pretreatments". They typically start with size reduction by chipping and grinding. In addition to being a rate-limiting step, a chemical pretreatment increases the cost of bioethanol production due to the high-energy requirements of heating and mechanical size reduction. Energy consumption during size reduction of wood may surpass $0.1-0.4 \mathrm{MJ} / \mathrm{kg}$, which is the required energy consumption to achieve sensible net energy output from wood to ethanol production (Kumar et al., 2009). Chemical separation of lignin and carbohydrates can be achieved through the use of acids, alkalies, and solvents, which promote selective solubilisation of either component. If acidic, carbohydrates solubilise; if alkaline, lignin degrades and solubilises (Mosier et al., 2005); if with solvents -widely known as organosolv pretreatment- carbohydrates solubilise (Zhao et al., 2009). Chemical processes may not be as selective as biological processes but may represent advantages related to required time, scalability, and process control.

Biological delignification can be conducted using either microorganisms, which produce a set of enzymes that work synergically, or purified enzymes. The most widely used microorganisms are fungi from the Basidiomysetes family. Nevertheless, bacteria from Pseudomonas, Flavobacteria, Xanthomonas, Bacillus, Aeromonas and Cellulomonas strains can also decompose lignin and its derivatives. Biological lignin degradation can be conducted by culturing the microorganism in submerged, semisolid or solid cultures where enzymes such as lignin peroxidase, xylanase, laccase, and manganese peroxidase (among others) perform selective lignin degradation. 
In this chapter, the reactions that lead to delignification of feedstocks in several different choices of chemical and biological pretreatments are discussed. In addition, other compositional changes during pretreatment are briefly reviewed. Although some basic chemical aspects related to lignocelluloses compositional analysis is presented here, it is out of the scope of this chapter to make a deep chemical discussion on this subject. All throughout the text, the reader is referred to several recent reviews and key articles for more detailed discussions.

\section{Generalities of lignocellulosic compounds}

Lignocellulose is the major renewable organic matter with an estimated production of about $200 \times 10^{9}$ tons per year (Reddy \& Yang, 2005). This is mainly constituted by lignin and cell wall polysaccharides such as cellulose, pectins, and hemicelluloses, which may be valuable substrates for biofuels production. Lignin is found in the cell wall and sometimes within woody tissue in quantities that vary widely depending on the type of plant, the part of the plant, and its age. Klason lignin is reported to range between 8 and $22 \%$ for herbaceous crops and between 19 to $30 \%$ for woody crops (Hatakeyama \& Hatakeyama, 2005). Lignins are complex natural polymers resulting from oxidative coupling of, primarily, 4hydroxyphenylpropanoids. The monomers conforming lignin are p-coumaril, conyferil, and sinapyl alcohols. They differ from each other in the degree of methoxylation (Fig. 1). The proportion in which they are present in lignin varies widely depending on the type of plant. These monomers produce p-hydroxyphenyl, guaiacyl, and syringyl phenylpropanoid units (Fig. 1), which are capable of generating electron delocalized radicals that couple at various sites (Boerjan et al., 2003). These monomers can form under different chemical routes dimmers or participate in lignifications. Some basic linkages between lignin monomers are illustrated in Fig. 1. For a deeper discussion refer to Boerjan et al. (2003).

Cellulose is constituted entirely by glucan chains linked by $\beta(1 \rightarrow 4)$ bonds which interact with each other via hydrogen bonds (Keegstra, 2010). Hemicelluloses on the other hand, are constituted by backbones of glucose $\beta(1 \rightarrow 4)$ linked, mannose, and xylose with an equatorial configuration. Consequently, hemicelluloses include xylans (mainly), glucans, mannans, glucomannans, and xyloglucans (Scheller \& Ulvskov, 2010).

\subsection{Physic-chemical properties of lignin}

Complete studies and reviews of the chemistry and physic-chemical properties of lignin were reported in the ACS symposium 397 (Glasser \& Sarkanen, 1989), and by few authors (Agarwal \& Atalla, 2010; Hatakeyama \& Hatakeyama, 2010a; 2010b; Hatakeyama \& Hatakeyama, 2005; Ralph \& Landucci, 2010; Schmidt, 2010). A brief summary of these revisions is presented here. Readers seeking a greater detail should consult the aforementioned references.

Lignin molecular mass ranges from $10^{3}$ and $10^{5}$ depending on plant species and variations. The reported values may also be influenced by extracting or processing methods and analytic techniques. Soluble lignin presents a discrete maximum absorbance at 205 or 280 $\mathrm{nm}$, with an extinction coefficient $(\varepsilon)$ varying according to the lignin source and the used solvent. It also presents a characteristic fluorescence with a broad maximum emission ranging from 400 to $500 \mathrm{~nm}$, depending on the excitation wavelength. Lignin is an amorphous polymer and presents a broad distribution of molecular arrangements, with 
intra- and intermolecular distances that can vary from 0.40 to $0.98 \mathrm{~nm}$. The glass transition of lignin in solid state does not present first order thermodynamic transitions; and at temperatures lower than the decomposition temperature, lignin can adopt a glassy or rubbery state. It has been shown that the heat capacity and intermolecular distance increase at the glass transition temperature $\left(T_{g}\right)$. Also, $T_{g}$ increases linearly with increments in lignin molecular weight, and strongly depends on the thermal history of the lignin sample. For example, $T_{g}$ in kraft lignin is close to $100{ }^{\circ} \mathrm{C}$, while it varies between 70 to $85{ }^{\circ} \mathrm{C}$ for hydrolysis lignin. Since the solidification rate affects the enthalpy of glassy lignin, enthalpy of the glassy state decreases when a lignin sample is slowly cooled from the melt. On the other hand, if the sample is quenched, the enthalpy increases since molecular chains are more randomly frozen than those of slowly glassified samples. Then, in samples below $T_{g}$ the measured enthalpy of glassy polymers decreases as a function of time. This is called enthalpy relaxation, which is monitored through heat capacity change at glass transition.<smiles>OC/C=C/c1ccc(O)cc1</smiles>

(a)<smiles>COc1ccc(/C=C/CO)cc1O</smiles>

(b)<smiles>COc1cc(/C=C/CO)cc(OC)c1O</smiles>

(c)<smiles>COc1ccc(Br)cc1I</smiles>

(d)<smiles>[3H]c1ccc(OC)c(OC)c1</smiles>

(e)<smiles>COc1cc([12F])cc(OC)c1O</smiles>

(f)<smiles></smiles>

(g)

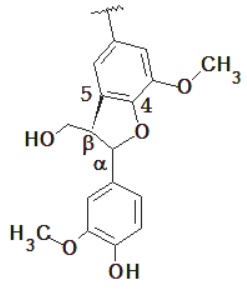

(h)<smiles>COc1cc(C2PC3CC2COC3c2cc(I)c(O)c(OC)c2)cc(C)c1O</smiles>

(i)

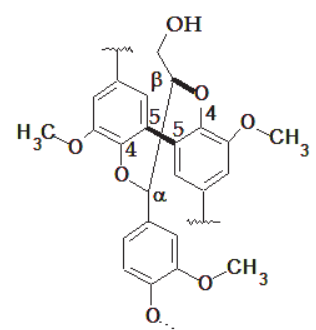

(j)

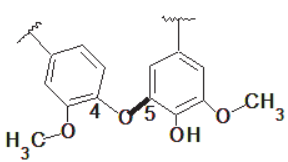

(k)<smiles>COc1cc(C(C)(C)C)cc(-c2cc(C(C)(C)C)cc(OC)c2O)c1O</smiles>

(1)

Fig. 1. Lignin monomers p-coumaril (a), conyferil (b) and sinapyl (c) alcohols, and their units inside lignin p-hydroxyphenyl (d), guaiacyl (e), and syringyl (f). Major structural units of lignin and presence in softwood (sw) and hardwood (hw), (g) $\beta-\mathrm{O}-4$ unit ( $\beta$ - aryl ether), sw: $50 \%$ and hw: $60 \%$; (h) $\beta-5$ ( $\alpha-\mathrm{O}-4)$ unit (phenylcoumaran), sw: $11 \%$ and hw $6 \%$; (i) $\beta-\beta$ unit (resinol), sw and hw $\sim 2 \%$; (j) [5-5/ $\beta-\mathrm{O}-4(\alpha-\mathrm{O}-4)]$ unit (dibenzodioxocin); (k) 4-O-5 unit (biphenyl ether), sw and hw $5 \%$; (l) 5-5 unit (biphenyl), sw: $18 \%$ and hw: $10 \%$ (Boerjan et al., 2003; Dimmel, 2010). 


\subsection{Chemical composition of agro-industrial wastes and by-products}

Knowledge of chemical components of agro-industrial wastes produced worldwide should precede any attempt for fuel production. Although it is difficult to establish the major agroindustrial crops and their by-products generated worldwide, this work presents in Table $1 \mathrm{a}$ selection of agro-industrial by-products based on their use for bioethanol production, and major crops reported by the FAO (2008) for the most populated countries in the word (China, India, US, Indonesia, Brazil, Bangladesh, Nigeria, Russia and Japan). This is according to the Population Reference Bureau (PRB, 2010).

\section{Biological delignification}

The production of alcohols from lignocellulosic materials involve two steps: 1) the hydrolysis of macromolecules (cellulose, hemicellulose, lignin and xylose) to release the carbohydrates that are further depolymerized to produce free sugars, and 2) the fermentation of these free sugars (Martinez et al., 2009; Perez et al., 2002). Among the lignocellulose constituent macromolecules, lignin is the most recalcitrant due to its amorphous hydrophobic heteropolymeric nature (Martinez et al., 2009). Although chemical/thermal processes allow good delignification levels, biodelignification has mild reaction conditions, higher product yields, few side reactions, less energy demand, and less reactor requirements to resist pressure and corrosion, which makes the bio-delignification a promissory pre-treatment for the production of biofuels. However, bio-delignification takes much longer than chemical or thermal processes, usually 8-12 weeks (Yu et al., 2010a), showing the importance of exploring new microorganisms, and the improving of culture conditions. Tables 2 and 3 summarize some fungi and bacteria used for bio-delignification of lingocellulosic materials.

\subsection{Delignifying enzymes}

Bio-delignification can be produced by the action of lignin peroxidase ( $\mathrm{LiP}$ ), manganese peroxidase $(\mathrm{MnP})$, laccase, and versatile peroxidase (VP). Although up to now it has not been described a microorganism producing all the ligninolytic enzymes, the presence of two or more enzymes have been associated with higher delignification levels than those observed with the isolated enzymes showing the synergistic action of this set of enzymes (Costa et al., 2002; Gonçalves et al., 1998; Kannan et al., 1990).

\subsubsection{Lignin peroxidase}

LiP [EC 1.11.1.14] has been mainly isolated from Phanerochaete chrysosporium. Nevertheless, LiPs have been also found in other white- and brown-rot fungi strains, Aspergilllus strains, and bacteria such as Acinetobacter calcoaceticus, Streptomyces viridosporus and Streptomyces lividans (Crawford et al., 1993; Ghodake et al., 2009; Zerbini et al., 1999). LiPs are glycosilated enzymes of about 340 amino acids with a molecular weight between 38 and $50 \mathrm{kDa}$, a single heme, and two calcium ions (Hammel \& Cullen, 2008; Sinclair et al., 1992). LiPs isozymes of $P$. chrysosporium are encoded by a family of 10 closely related and well-characterized genes (Hammel \& Cullen, 2008), while in Trametes versicolor the LiP gene is arranged into a gene cluster encoding for two LiP and one MnP (Johansson \& Nyman, 1996), and bacterial LiP seems to be encoded only for one gene (Wang et al., 1990). 


\begin{tabular}{|c|c|c|c|c|c|c|c|c|}
\hline By-product & Country & $\mathrm{Lc}^{\mathrm{c}}$ & G & $X$ & $\mathbf{A}$ & $\mathrm{C}$ & $\mathbf{H}$ & Reference \\
\hline Corn storver & US & 13.3 & 31.9 & 18.9 & 2.8 & & & (Templeton et al., 2009) \\
\hline Cotton stalk & China & 19.75 & & & & 35.60 & 21.88 & (Zhang et al., 2010) \\
\hline Sugarcane baggase & Brazil & 22.8 & 43.4 & 24.4 & 2.0 & & & $\begin{array}{l}\text { (Carrasco et al., 2010; } \\
\text { Guo et al., 2009) }\end{array}$ \\
\hline $\begin{array}{c}\text { Oil palm (empty fruit } \\
\text { bunches) }\end{array}$ & Colombia & 4.15 & & & & 46.77 & 17.92 & (Piarpuzán et al., 2011) \\
\hline Silvergrass & $\underset{a, b}{\text { Europe }}$ & $\begin{array}{l}7.6- \\
11.5\end{array}$ & & & & $\begin{array}{l}43.0- \\
52.2\end{array}$ & $\begin{array}{l}24.8- \\
33.9\end{array}$ & (Hodgson et al., 2010) \\
\hline $\begin{array}{l}\text { Switchgrass } \\
\text { (Panicum sp.) }\end{array}$ & US & 21.4 & 35.0 & 21.8 & 3.5 & & & (Garlock et al., 2011) \\
\hline Rice straw & China & $\begin{array}{l}7.2- \\
12.8\end{array}$ & & & & $\begin{array}{l}30.3- \\
38.2\end{array}$ & $\begin{array}{l}19.8- \\
31.6\end{array}$ & (Jin \& Chen, 2007) \\
\hline Wheat straw & Canada & 18.15 & 38.27 & 18.75 & 1.5 & & & (Tamaki \& Mazza, 2010) \\
\hline Oat straw & India & 15.5 & & & & 36.0 & 48.5 & $\begin{array}{c}\text { (Pandey \& Pandey, } \\
\text { 2002) }\end{array}$ \\
\hline Barley straw & Russia & 22.2 & & & & 41.3 & 19.5 & (Kocheva et al., 2008) \\
\hline Rye straw & Russia & 20.5 & & & & 49.0 & 17.4 & (Kocheva et al., 2008) \\
\hline Soya stalks & Russia & 25.4 & & & & 37.6 & 17.3 & (Torgashov et al., 2010) \\
\hline Coconut husk & Malaysia & 32.8 & & & & 44.2 & 12.1 & (Khalil et al., 2006) \\
\hline Eucalyptus wood & China & 26.2 & 44.9 & 11.4 & & & & (Yu et al., 2010c) \\
\hline Sunflower stalks & India & 17.5 & & & & 38.5 & 33.5 & (Sharma et al., 2002) \\
\hline Sorghum stover & China & 14.3 & 27.3 & 13.1 & 1.4 & & & (Li et al., 2010) \\
\hline Cassava baggase & Thailand & 2.2 & 19.1 & 4.2 & 1.4 & & & (Kosugi et al., 2009) \\
\hline Olive wood & Spain & 20.4 & & & & 34.4 & 20.3 & (Ruiz et al., 2006) \\
\hline Eucalyptus wood & $\begin{array}{l}\text { Brazil } \\
\text { China }\end{array}$ & $\begin{array}{l}27.1 \\
26.2\end{array}$ & \begin{tabular}{|}
51.49 \\
44.9
\end{tabular} & $\mid \begin{array}{c}13.11 \\
11.4\end{array}$ & 0.47 & & & $\begin{array}{l}\text { (Brito et al., 2008) } \\
\text { (Yu et al., 2010c) }\end{array}$ \\
\hline $\begin{array}{l}\text { Construction wood } \\
\text { waste }\end{array}$ & Korea & $\begin{array}{l}22.7- \\
25.3\end{array}$ & & $6.3-9$ & & $\begin{array}{l}45.4- \\
51.2\end{array}$ & & (Cho et al., 2011) \\
\hline Pinus wood & US & 26.8 & & 6.6 & 1.6 & 43.6 & & (Frederick Jr et al., 2008) \\
\hline
\end{tabular}

a Samples were taken in three countries: Germany, Denmark and Sweden. b Variations are due to the Miscanthus species and harvest season. ${ }^{c}$ Lignin composition refers to total acid- soluble and insoluble lignin. N.D: Not determined.

Table 1. Composition of major agro-industrial by-products use in delignification processes to obtain fermentable carbohydrates (L, lignin; G, glucan; X, xylan; A, arabian or arabinosyl substituents; $\mathrm{C}$, cellulose, and $\mathrm{H}$, hemicellulose). 


\begin{tabular}{|c|c|c|c|c|c|c|c|}
\hline \multirow[t]{2}{*}{ Strain } & \multicolumn{3}{|c|}{ Culture Conditions } & \multirow{2}{*}{\begin{tabular}{|c|}
$L^{*}$ \\
$(\%)$
\end{tabular}} & \multirow[t]{2}{*}{ Substrate } & \multirow[t]{2}{*}{ Remarks } & \multirow[t]{2}{*}{ Reference } \\
\hline & Process & $\begin{array}{c}\text { Temp. } \\
\left({ }^{\circ} \mathrm{C}\right)\end{array}$ & $\begin{array}{c}\text { Time } \\
\text { (d) }\end{array}$ & & & & \\
\hline $\begin{array}{l}\text { Aspergillus } \\
\text { niger }\end{array}$ & SS & 55 & 0.08 & 20 & $\begin{array}{c}\text { Cellulose } \\
\text { pulp }\end{array}$ & $\begin{array}{c}\text { Crude extract containing } \\
\text { xylanases }\end{array}$ & (Betini et al., 2009) \\
\hline $\begin{array}{l}\text { Aspergillus } \\
\text { niveus }\end{array}$ & SS & 55 & 0.08 & 20 & $\begin{array}{c}\text { Cellulose } \\
\text { pulp }\end{array}$ & $\begin{array}{c}\text { Crude extract containing } \\
\text { xylanases }\end{array}$ & (Betini et al., 2009) \\
\hline $\begin{array}{l}\text { Aspergillus } \\
\text { ochraceus }\end{array}$ & SS & 55 & 0.08 & 20 & $\begin{array}{c}\text { Cellulose } \\
\text { pulp }\end{array}$ & $\begin{array}{c}\text { Crude extract containing } \\
\text { xylanases }\end{array}$ & (Betini et al., 2009) \\
\hline \multirow[t]{3}{*}{$\begin{array}{l}\text { Ceriporiopsis } \\
\text { subvermispora }\end{array}$} & SS & 27 & 30 & 20 & $\begin{array}{c}\text { Sugarcane } \\
\text { bagasse }\end{array}$ & $\begin{array}{c}\text { Xylanase and } \mathrm{MnP} \\
\text { production }\end{array}$ & (Costa et al., 2005) \\
\hline & SS & 25 & 60 & N.S. & \begin{tabular}{|c|} 
Paddy \\
straw
\end{tabular} & Cellulose lost. & $\begin{array}{c}\text { (Sharma \& Arora, } \\
\text { 2010) }\end{array}$ \\
\hline & SS & 28 & 42 & 32 & $\begin{array}{l}\text { Corn } \\
\text { stover }\end{array}$ & $\begin{array}{c}\text { Improvement in sugar } \\
\text { hydrolysis }\end{array}$ & (Wan \& Li, 2010) \\
\hline $\begin{array}{c}\text { Echinodontium } \\
\text { taxodii }\end{array}$ & Sm & 25 & 30 & 42 & Corn straw & $\begin{array}{c}\text { Enhanced efficiency of } \\
\text { alkaline/oxidative } \\
\text { treatment }\end{array}$ & (Yu et al., 2010b) \\
\hline Euc-1 & SS & 28 & 35 & 55 & $\begin{array}{l}\text { Wheat } \\
\text { straw }\end{array}$ & $\begin{array}{l}\text { Laccase, } \mathrm{MnP} \text { and } \mathrm{LiP} \\
\text { production }\end{array}$ & (Dias et al., 2010) \\
\hline $\begin{array}{c}\text { Gleophyllum } \\
\text { trabeum }\end{array}$ & SS & 27 & 12 & 0 & \begin{tabular}{|l|}
$\begin{array}{l}\text { Wood } \\
\text { chips }\end{array}$ \\
\end{tabular} & $\begin{array}{c}68 \% \text { of carbohydrate } \\
\text { degradation }\end{array}$ & (Fissore et al., 2010) \\
\hline $\begin{array}{l}\text { Gonoderma } \\
\text { lacidum }\end{array}$ & Sm & 25 & 30 & 55 & Corn straw & $\begin{array}{c}\text { Enhanced efficiency of } \\
\text { alkaline/oxidative } \\
\text { treatment }\end{array}$ & (Yu et al., 2010b) \\
\hline \multirow[t]{2}{*}{ Irpex lacteus } & SS & 28 & 35 & 55 & $\begin{array}{l}\text { Wheat } \\
\text { straw }\end{array}$ & $\begin{array}{c}\text { MnP and LiP } \\
\text { production }\end{array}$ & (Dias et al., 2010) \\
\hline & SS & 28 & 15 & 12 & Corn stalks & $\begin{array}{c}\text { Combination with mild } \\
\text { alkaline pretreatment } \\
\text { allowed } 80 \% \text { lignin } \\
\text { reduction }\end{array}$ & (Yu et al., 2010a) \\
\hline Oxysporus sp. & $\mathrm{Sm}$ & 25 & 60 & 69 & \begin{tabular}{|c|}
$\begin{array}{c}\text { Pomace } \\
\text { from olive } \\
\text { oil }\end{array}$ \\
\end{tabular} & \begin{tabular}{|l|} 
Laccase production \\
\end{tabular} & $\begin{array}{l}\text { (Haddadin et al., } \\
\text { 2002) }\end{array}$ \\
\hline \begin{tabular}{|c|} 
Panos tigrinus \\
strains
\end{tabular} & SS & 30 & 10 & $\begin{array}{c}4 \text { to } \\
7\end{array}$ & $\begin{array}{c}\text { Sugarcane } \\
\text { bagasse }\end{array}$ & $\begin{array}{c}\text { Expression of } \mathrm{MnP}, \mathrm{LiP} \\
\text { and lacasse }\end{array}$ & $\begin{array}{c}\text { (Gonçalves et al., } \\
1998)\end{array}$ \\
\hline $\begin{array}{c}\text { Penicillium } \\
\text { oxalicum + } \\
\text { Pleurotus } \\
\text { osteatus }\end{array}$ & SS & N.S. & 0.125 & 21 & Wood pulp & $\begin{array}{c}\text { Synergistic action of } \\
\text { crude extract containing } \\
\text { xylanase and laccase }\end{array}$ & (Dwivedi et al., 2010) \\
\hline \multirow[t]{2}{*}{\begin{tabular}{|l|} 
Phanerochaete \\
chrysosporium
\end{tabular}} & Sm & 39 & 14 & 34 & $\begin{array}{l}\text { Cotton } \\
\text { stalks }\end{array}$ & $\begin{array}{l}\text { Improvement in } \\
\text { carbohydrate } \\
\text { availability }\end{array}$ & (Shi et al., 2009) \\
\hline & SS & 39 & 10 & 21 & $\begin{array}{l}\text { Cotton } \\
\text { stalks }\end{array}$ & $\begin{array}{l}\text { Improvement in } \\
\text { carbohydrate } \\
\text { availability }\end{array}$ & (Shi et al., 2009) \\
\hline $\begin{array}{l}\text { Phlebia } \\
\text { brevispora }\end{array}$ & SS & 25 & 60 & N.S. & $\begin{array}{l}\text { Paddy } \\
\text { straw }\end{array}$ & Cellulose lost. & $\begin{array}{c}\text { (Sharma \& Arora, } \\
\text { 2010) }\end{array}$ \\
\hline
\end{tabular}




\begin{tabular}{|c|c|c|c|c|c|c|c|}
\hline \multirow[t]{2}{*}{ Strain } & \multicolumn{3}{|c|}{ Culture Conditions } & \multirow{2}{*}{$\begin{array}{l}L^{*} \\
(\%)\end{array}$} & \multirow[t]{2}{*}{ Substrate } & \multirow[t]{2}{*}{ Remarks } & \multirow[t]{2}{*}{ Reference } \\
\hline & Process & $\mid \begin{array}{c}\text { Temp. } \\
\left({ }^{\circ} \mathrm{C}\right)\end{array}$ & $\begin{array}{l}\text { Time } \\
\text { (d) }\end{array}$ & & & & \\
\hline $\begin{array}{l}\text { Phlebia } \\
\text { floridensis }\end{array}$ & SS & 25 & 60 & N.S. & $\begin{array}{l}\text { Paddy } \\
\text { straw }\end{array}$ & Cellulose lost. & $\begin{array}{c}\text { (Sharma \& Arora, } \\
\text { 2010) }\end{array}$ \\
\hline $\begin{array}{l}\text { Phlebia } \\
\text { radiate }\end{array}$ & SS & 25 & 60 & N.S. & $\begin{array}{l}\text { Paddy } \\
\text { straw }\end{array}$ & Cellulose lost. & $\begin{array}{c}\text { (Sharma \& Arora, } \\
\text { 2010) }\end{array}$ \\
\hline $\begin{array}{l}\text { Pycnoporus } \\
\text { cinnabarinus }\end{array}$ & SS & 24 & 30 & 12 & \begin{tabular}{|c|}
$\begin{array}{c}\text { Sugarcane } \\
\text { bagasse }\end{array}$ \\
\end{tabular} & $\begin{array}{l}\text { No cellulose } \\
\text { degradation }\end{array}$ & (Meza et al., 2006) \\
\hline \multirow[t]{4}{*}{$\begin{array}{l}\text { Pycnoporus } \\
\text { sanguineus }\end{array}$} & Sm & 30 & 21 & 25 & $\begin{array}{l}\text { Wheat } \\
\text { straw }\end{array}$ & & (Lu et al., 2010) \\
\hline & Sm & 28 & 1 & 71 & $\begin{array}{l}\text { Wheat } \\
\text { straw }\end{array}$ & $\begin{array}{c}\text { Native and recombinant } \\
\text { laccase }\end{array}$ & (Lu et al., 2010) \\
\hline & $\mathrm{Sm}$ & 30 & 21 & 27 & $\begin{array}{l}\text { Corn } \\
\text { strover }\end{array}$ & & (Lu et al., 2010) \\
\hline & $\mathrm{Sm}$ & 28 & 1 & 57 & $\begin{array}{l}\text { Corn } \\
\text { strover }\end{array}$ & $\begin{array}{c}\text { Native and recombinant } \\
\text { laccase }\end{array}$ & (Lu et al., 2010) \\
\hline \multirow[t]{2}{*}{$\begin{array}{l}\text { Pynnoporus } \\
\text { cinnabarinus }\end{array}$} & SS & 30 & 15 & 12 & $\begin{array}{l}\text { Prosopis } \\
\text { juliflora }\end{array}$ & $\begin{array}{l}20 \% \text { increment in sugar } \\
\text { release }\end{array}$ & (Gupta et al., 2010) \\
\hline & SS & 30 & 15 & 8 & $\begin{array}{l}\text { Lantana } \\
\text { camara }\end{array}$ & $\begin{array}{c}20 \% \text { increment in sugar } \\
\text { release }\end{array}$ & (Gupta et al., 2010) \\
\hline $\begin{array}{l}\text { Trametes } \\
\text { versicolor }\end{array}$ & $\mathrm{Sm}$ & 25 & 30 & 52 & Corn straw & $\begin{array}{c}\text { Enhanced efficiency of } \\
\text { alkaline/oxidative } \\
\text { treatment }\end{array}$ & (Yu et al., 2010b) \\
\hline
\end{tabular}

Table 2. Fungus strains used for the delignification of lignocelullose materials. $\mathrm{L}^{*}=$ Lignin Lost, $\mathrm{Sm}=$ Submerged Fermentation, $\mathrm{SS}=$ Solid-state fermentation, $\mathrm{MnP}=$ Manganese peroxidase, $\mathrm{LnP}=$ Lignin peroxidase, N.S. $=$ Non specified.

\begin{tabular}{|c|c|c|c|c|c|c|c|}
\hline \multirow[t]{2}{*}{ Strain } & \multicolumn{3}{|c|}{ Culture Conditions } & \multirow{2}{*}{$\begin{array}{c}\mathrm{L} \\
(\%)\end{array}$} & \multirow{2}{*}{ Substrate } & \multirow[t]{2}{*}{ Remarks } & \multirow[t]{2}{*}{ Reference } \\
\hline & $\begin{array}{c}\text { Proces } \\
\mathrm{s}\end{array}$ & $\begin{array}{l}\text { Temp. } \\
\left({ }^{\circ} \mathrm{C}\right)\end{array}$ & \begin{tabular}{|c|} 
Time \\
(d)
\end{tabular} & & & & \\
\hline $\begin{array}{l}\text { Bacillus } \\
\text { macerans }\end{array}$ & SS & 28 & 45 & 50 & Cotton saw & & (Singh et al., 2008) \\
\hline $\begin{array}{l}\text { Bacillus } \\
\text { pamilus }\end{array}$ & $\mathrm{Sm}$ & 55 & 2 & 8 & Kraft-pulp & Cellulase-free & (Kaur et al., 2010) \\
\hline Bacillus sp. & $\mathrm{Sm}$ & 35 & 2 & 56 & \begin{tabular}{|c|} 
Pulp and \\
paper mill \\
effluent
\end{tabular} & $\begin{array}{l}\text { Xylanase and } \mathrm{MnP} \\
\text { production }\end{array}$ & $\begin{array}{c}\text { (Mishra \& Thakur, } \\
\text { 2010) }\end{array}$ \\
\hline $\begin{array}{c}\text { Cellulomonas } \\
\text { cartae }\end{array}$ & SS & 28 & 45 & 50 & Cotton saw & & (Singh et al., 2008) \\
\hline $\begin{array}{c}\text { Cellulomonas } \\
\text { uda }\end{array}$ & SS & 28 & 45 & 50 & Cotton saw & & (Singh et al., 2008) \\
\hline $\begin{array}{c}\text { Zymomonas } \\
\text { mobilis }\end{array}$ & SS & 28 & 45 & 33 & Cotton saw & & (Singh et al., 2008) \\
\hline
\end{tabular}

Table 3. Bacteria strains used for the delignification of lignocelullose materials. $\mathrm{L}^{*}=$ Lignin Lost, $\mathrm{Sm}=$ Submerged Fermentation, $\mathrm{SS}=$ Solid-state fermentation, $\mathrm{MnP}=$ Manganese peroxidase, $\mathrm{LnP}=$ Lignin peroxidase, N.S. $=$ Non specified . 
Due to the complex nature of lignin, the delignification process must be carried out extracellulary, and the LiP is found in all the peripheral regions of the fungal cell cytoplasm in association with the cell membrane, fungal cell wall, and extracellular slime materials (Daniel et al., 1989). In addition, in solid wood LiP is detected in low concentrations associated with both superficial and degradation zones within secondary cell walls undergoing fungal attack, while in liquid cultures (i.e. submerged-state fermentation) a much greater level of extracellular peroxidase activity is associated with wood fragments degraded by fungus. Although LiP is able to oxidize aromatic compounds with a high redox potentials by single electron abstraction and is the most efficient lignin-degrading enzyme (Piontek et al., 2001), in vitro the majority of lignin-derived preparations actually experience overall polymerization after LiP exposure (Sarkanen et al., 1991). LiP activity is controlled by the ionization degree suggesting that specifics amino acids residues play a role in lignin binding, and that this enzyme is capable of oxidizing lignin directly at the protein surface by a long-range electron transfer process (Johjima et al., 1999).

LiPs degrade lignin through $\mathrm{H}_{2} \mathrm{O}_{2}$ using a mechanism that resembles that used for other peroxidades (Hammel \& Cullen, 2008; Martinez et al., 2005; Wong, 2009). The first step involves the formation of a high redox potential oxo-ferryl intermediate (compound I, LiP-I) as result of the reaction of the heme cofactor with $\mathrm{H}_{2} \mathrm{O}_{2}$. In a second step two consecutive $1 \mathrm{e}^{-}$ reductions are carried out (Fig. 2): (i) a $1 \mathrm{e}^{-}$reduction of $\mathrm{LiP}$ by a reducing substrate yields to compound II (LiP-II) and a substrate radical cation, and (ii) a $1 \mathrm{e}^{-}$reduction that returns the enzyme to the ferric oxidation state, completing the catalytic cycle (Wong, 2009). The radical cation of the substrate produced in this cycle undergoes rearrangements and non-enzymatic degradations (Fig. 2), which in turn leads to a set of reactions that results in lignin depolymerization (Wong, 2009). Mutagenesis studies have shown that LiP has two distinct substrate interaction sites: (i) the classical heme edge, which degrades lignin-derived compounds and dyes, and (ii) the glutamine 146 site, which is implicated in catalysis of lignin-derived compounds.

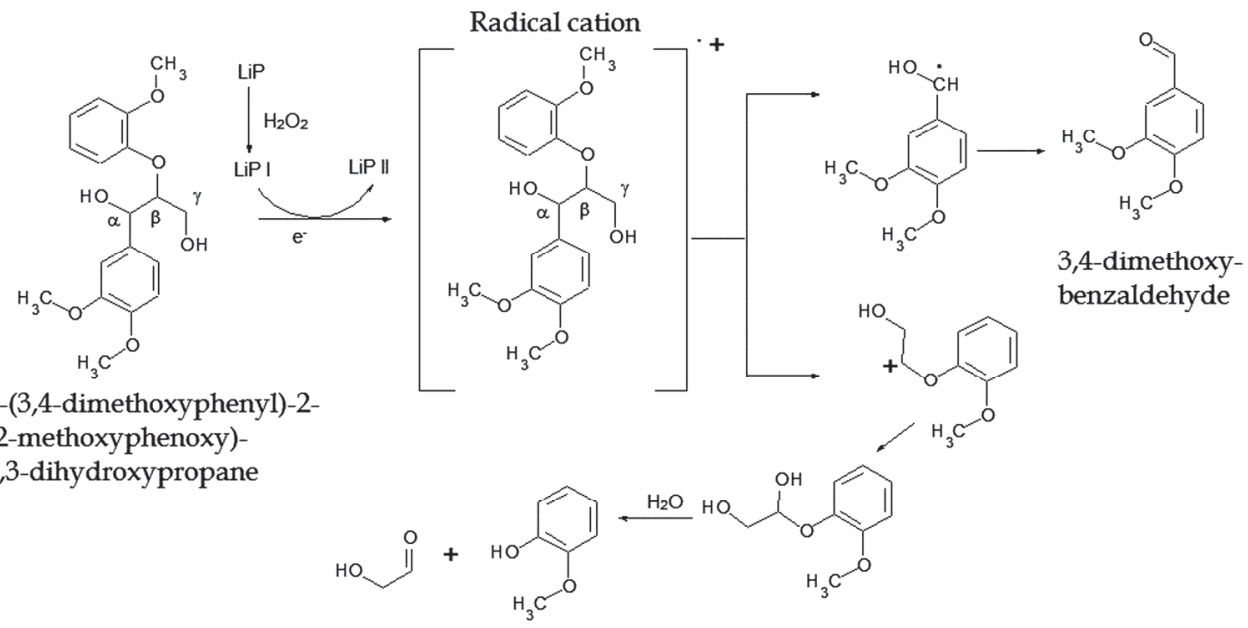

Fig. 2. LiP-catalyzed oxidation of non-phenolic $\beta$-O-4 lignin model compound. Modified from Wong (2009). 
LiP genes have been cloned and expressed in Phanerochaete sordida, Trichoderma reesei, Pichia pastoris, Pichia methanolica and Escherichia coli, obtaining recombinant enzymes with similar properties to those observed in native enzymes (Nie et al., 1998; Saloheimo et al., 1989; Sugiura et al., 2009; Wang \& Wen, 2009). A recent work showed that by coupling a directed evolution technique with a rapid colorimetric screening method, it was possible to obtain a recombinant $\mathrm{LiP}$ with improved $\mathrm{H}_{2} \mathrm{O}_{2}$ stability, polychlorinated phenol degradability, and kinetic properties (Ryu et al., 2008).

\subsubsection{Manganese peroxidase}

The MnPs [EC 1.11.1.13] share many of the characteristics previously discussed for LiPs. They are glycosilated, extracellular heme-containing enzymes of about 350 amino acids, a molecular weight around $40 \mathrm{kDa}$, and the same peroxidase catalytic cycle of $\mathrm{LiP}$ (Martinez et al., 2009; Martinez et al., 2005). MnP has been isolated mainly from basidiomycetes including P. chrysosporium, Schizophyllum sp., Ceriporiopsis subvermispora, Panus tigrinus, Lentinula edodes, Nematoloma frowardii, Bjerkandera adusta, T. versicolor, and Dichomitus squalens, among others. The presence of $\mathrm{MnP}$ has been also reported in an Aspergillus terreus strain (Kanayama et al., 2002). The enzyme production is specie- and strain-dependent, with an important role of the carbon source, the lignocellulosic substrate and the presence of aromatic compounds (Elisashvili \& Kachlishvili, 2009). Catalytic cycle of $\mathrm{MnP}$ is similar to that of LiP (Fig. 3): (i) compound I (MnP-I), a Fe(IV)-oxo-porphyrin radical cation, is produced by reaction of enzyme and $\mathrm{H}_{2} \mathrm{O}_{2}$, (ii) $\mathrm{Mn}^{2+}$ reduces compound I to compound II, producing $\mathrm{Mn}^{3+}$, and (iii) the resting enzyme is regenerated (Wong, 2009). This $\mathrm{Mn}^{3+}$ oxidizes phenolic substrates in a second-order reaction, producing phenoxy-radicals, which in turn led to a set of reactions that result in lignin depolymerization (Perez et al., 2002) (Fig. 3).

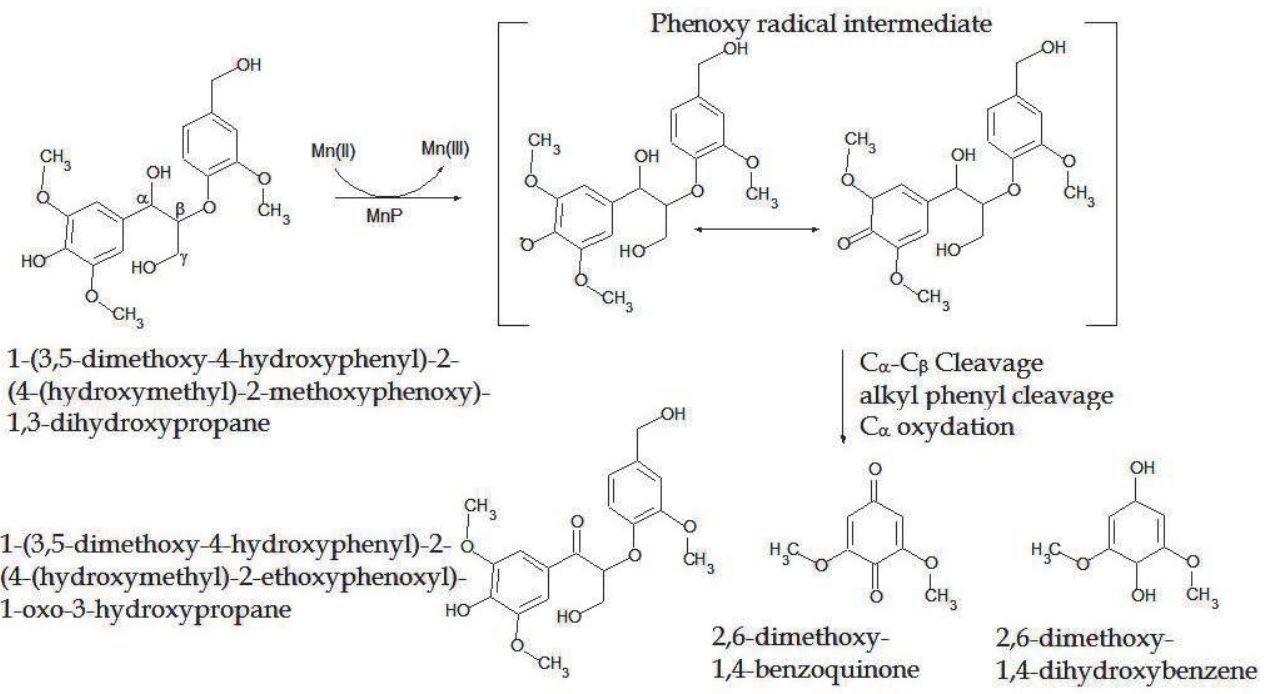

Fig. 3. MnP-catalyzed oxidation of phenolic aryglycerol $\beta$-aryl ether lignin model compound. Modified from Wong (2009). 
The $\mathrm{MnP}$ has a single binding site for $\mathrm{Mn}^{2+}$ near the heme, from which two $\mathrm{Mn}^{3+}$ equivalents are obtained at the expense of one $\mathrm{H}_{2} \mathrm{O}_{2}$ equivalent in a reaction requiring oxalate or another appropriate manganese chelator (Timofeevski \& Aust, 1997; Wariishi et al., 1992). However, $\mathrm{MnP}$ can also catalyze a manganese-dependent disproportionation of $\mathrm{H}_{2} \mathrm{O}_{2}$ in the absence of manganese chelator, which may protect the enzyme from inactivation by $\mathrm{H}_{2} \mathrm{O}_{2}$ under limited free oxalate conditions (Timofeevski \& Aust, 1997). Reaction of $\mathrm{Mn}^{3+}$ with $\mathrm{H}_{2} \mathrm{O}_{2}$ is catalyzed by $\mathrm{Cu}^{2+}$, which explains the inhibition of $\mathrm{MnP}$ by $\mathrm{Cu}^{2+}$ (Aitken \& Irvine, 1990). Active site and crystal structure analysis of P. chrysosporium $\mathrm{MnP}$, the most studied $\mathrm{MnP}$ enzyme, have shown that arginine 42 and acidic amino acids (i.e glutamic or aspartic acid) at positions 35, 45, 39 and 179 are involved in $\mathrm{Mn}^{2+}$ binding (Sundaramoorthy et al., 2010; Whitwam et al., 1997), while serine 172 seems to been involved in heme binding (AmbertBalay et al., 2000). MnP encoding genes have been cloned from several white-rot fungi strains, where up to three different genes have been reported each one encoding for a specific isoform (Alvarez et al., 2009; Martinez et al., 2009; Martinez et al., 2005). The expression of $\mathrm{MnP}$ genes is mainly regulated by $\mathrm{Mn}$ via a growth-stage-specific and concentration-dependent mechanism (Brown et al., 1991). $\mathrm{Cu}^{2+}, \mathrm{Zn}^{2+}, \mathrm{Ag}^{+}, \mathrm{Cd}^{2+}, \mathrm{Se}, \mathrm{H}_{2} \mathrm{O}_{2}$, ethanol, sodium arsenite, and 2,4-dichlorophenol, as well as heat shock regulate the $\mathrm{MnP}$ gene expression, while the co-administration with $\mathrm{Mn}$ significantly enhances the MnP production (Alvarez et al., 2009; Catal et al., 2008).

$\mathrm{MnP}$ genes have been homo- or heterologous expressed in P. chrysosporium, P. ostreatus, $P$. pastoris, Aspergillus oryzae, and Zea mays, producing recombinant enzymes with similar kinetic and stabilities properties to those observed for native enzymes (Clough et al., 2006; Gu et al., 2003; Jiang et al., 2008).

\subsubsection{Laccase}

Laccases [EC 1.10.3.2] are glycosilated multicopper enzymes, with wide molecular weights ranging from 50 to $140 \mathrm{kDa}$ (Gaitan et al., 2011; Wong, 2009). Unlike LiP and MnP, laccases are widely distributed in nature and can be found in plants, fungi, bacteria and insects (Dwivedi et al., 2011; Riva, 2006). Although transgenic plants over-expressing laccase genes have been used for energy production, phytoremediation, and alteration in phenolic metabolism (Riva, 2006), most of the delignification process have been carried out by using microorganisms. In fungi, where they play a role in the host-pathogen interaction during the first step of infection (Punelli et al., 2009), laccases have been found in Trametes versicolor, Trametes pubescens, Pycnoporus cinnabarinus, Myceliophthora thermophila, Pleurotus eryngii, Pleurotus ferulae, Pleurotus astreatus, Cerrena unicolor, Cyathus bulleri, Lentinula edodedes, and Agaricus blazei, among others. In bacteria the enzyme has been reported in Azospirrullum lipoferum, Marinomonas medierranea, Streptomyces griseus, Haloferax volcanii, and Bacillus subtilis. Laccases are monomeric or homopolymeric enzymes (Riva, 2006; Wong, 2009), and the cellular localization depends on the organism, with plant and fungal laccases as extracellular enzymes, while an intracellular localization is observed in most of the bacterial laccases (Diamantidis et al., 2000; Riva, 2006).

Laccase catalyze the monoelectric oxidation of phenolic and nonphenolic substrates to their corresponding reactive radicals in a reaction mediated by the four $\mathrm{Cu}$ atoms located at the catalytic core. During the substrate oxidation there is a reduction of one oxygen molecule to two water molecules and four radicals (Arora \& Sharma, 2010). The four copper atoms are arranged in three different groups: Type- 1 or blue $\mathrm{Cu}$, Type- 2 or normal $\mathrm{Cu}$ and Type- 3 or 
coupled binuclear $\mathrm{Cu}$ centers. These $\mathrm{Cu}$ atoms produce the lignin degradation in a threestep reaction: (i) the Type- $1 \mathrm{Cu}$ is reduced by oxidizing lignin, (ii) the electron is transferred from Type- $1 \mathrm{Cu}$ to Type-2 and Type-3 Cu cluster, and (iii) oxygen is reduced to water at Type-2 and Type-3 Cu centres (Dwivedi et al., 2011; Riva, 2006). Laccases can oxidize a wide range of substrates including polyphenols, methoxysubstituted phenols, and aromatic diamines, among others, through $\mathrm{C} \alpha-\mathrm{C} \beta$ cleavage, alkyl-aryl cleavage or $\mathrm{C}_{\alpha}$ oxidation (Fig. 4) (Arora \& Sharma, 2010; Wong, 2009). Since laccases use oxygen instead of the $\mathrm{H}_{2} \mathrm{O}_{2}$ uses for peroxidases, the toxic effect of this compound in cell viability can be avoided giving to the laccases an important role in early stages of delignification (Sterjiades et al., 1993). Due to the large size of laccases and the highly complex structure of lignin, in most cases it cannot be degraded directly, requiring the presence of intermediate substrates (i.e. chemical mediators), which oxidized radicals are able to induce the depolymerization of complex substrates (Riva, 2006).

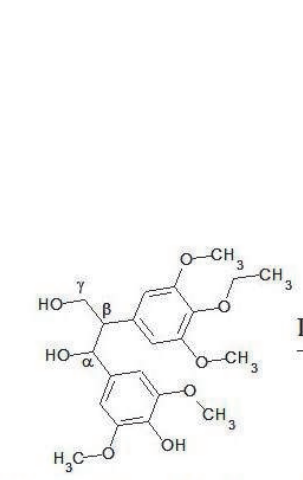

1-(3,5-dimethoxy-4-hydroxyphenyl) 2-(3,5-dimethoxy-4-ethoxyphenyl) propane-1,3-diol

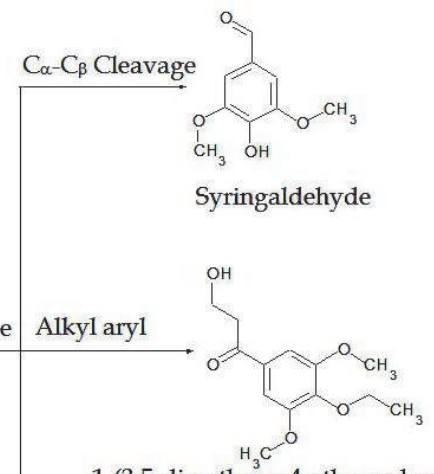

Syringaldehyde

1-(3,5-dimethoxy-4 ethoxyphenyl)3-hydroxypropanal

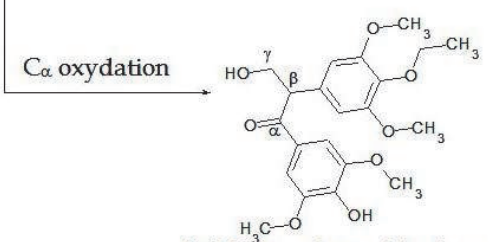

1-(3,5-dimethoxy-4-hydroxyphenyl)-2-(3,5-

dimethoxy-4-ethoxyphenyl)-3-hydroxypropanone

Fig. 4. Laccase-catalyzed oxidation of phenolic $\beta-1$ lignin model compound. Modified from Wong (2009).

Laccases are presented as up to six isoenzymes, with different molecular weights, expression profiles, stability, substrate affinity, and encoded by different genes (Dwivedi et al., 2011; Gaitan et al., 2011; Xiao et al., 2006). Laccase gene expression is mainly up regulated by $\mathrm{Cu}^{2+}$ addition, although other potent inducers are $\mathrm{Mn}^{2+}, \mathrm{Fe}^{3+}$, heavy metals, 2,6-dimethoxy-1,4-benzoquinone, $\mathrm{H}_{2} \mathrm{O}_{2}$, caffeine, amphotericin $\mathrm{B}$, syringic acid, tannic acid, Tween 80, soybean oil, aromatic compounds, and microclimatic changes (i.e. lower temperature and osmotic pressure) (Dekker et al., 2007; Galhaup et al., 2002; Xiao et al., 
2006). On the other hand, laccase production can be down-regulated or inhibited by proline, urea, glucose $\mathrm{Hg}^{2+}, \mathrm{Mg}^{2+}, \mathrm{Ca}^{2+}, \mathrm{Sn}^{2+}, \mathrm{Ba}^{2+}, \mathrm{Co}^{2+}, \mathrm{Cd}^{2+}, \mathrm{Mn}^{2+}$, and $\mathrm{Zn}^{2+}$, fatty acids, sulfydryeagents, hydroxyglycine, kojic acid, EDTA, l-cysteine, dithiothreitol, glutathione, thiourea, and cationic quaternary ammonium detergents; by chelating the $\mathrm{Cu}$ atoms, by modifying amino acid residues or by causing conformational changes in the glycoprotein (Dekker et al., 2007; Dwivedi et al., 2011; Galhaup et al., 2002).

Laccase genes have been cloned and expressed in Pichia pastoris, P. methanolic, Kluyveromyces lactis, Aspergillus niger, Coriolus versicolor, and E. coli, with significantly higher levels and similar or even better kinetic and stability profiles than those observed for native enzymes (Guo et al., 2006; Hong et al., 2007; Ranieri et al., 2009; Rodriguez et al., 2008; Salony et al., 2008).

\subsection{Fungi delignification}

During the last two decades white-rot fungi strains have shown to produce the more efficient delignification (Martinez et al., 2009; Vicuña, 2000; Wong, 2009) Phanerochaete chrysosporium is the most studied white-rot fungi used in biodelignification, with lignin reduction levels ranging from 11 to $73 \%$ and incubation times between 10 to 60 days. However, the differences among the substrates (i.e. rice straw, cotton stalks, mustard straw and sugarcane bagasse) and the culture conditions (e.g. solid-state fermentation-SSF, submerged fermentation-SmF, temperature and time), limit the comparison between the studies.

Shi et al. (2009), showed that higher lignin lost was observed in SmF than in SSF delignification of cotton stalks, while a 73\% lignin lost of kraft pulp was observed with SmF while no delignification was observed in SSF (Pellinen et al., 1989). Wheat straw and sugarcane bagasse, two important substrates for biofuels production (Kaparaju et al., 2009; Vasquez et al., 2007), showed low lignin degradation by $P$. chrysosporium strains (Dorado et al., 1999; Li et al., 2002). Similar results were observed for sugarcane bagasse delignification with Panos tigrinus (Gonçalves et al., 1998), Phanerochaete sordida (Li et al., 2002) and Pycnoporus cinnabarinus (Meza et al., 2006), showing the recalcitrant nature of this substrate for delignification. However, delignification levels above $50 \%$ were observed with Irpex lacteus for wheat straw (Dias et al., 2010) and Phlebia sp. for sugarcane bagasse (Li et al., 2002; Osono \& Takeda, 2006). Significant delignification results have also been reported for Coriolus versicolor (Tripathi et al., 2008), Echinodontium taxodii (Yu et al., 2010b), Euc-1 (Dias et al., 2010), Gonoderma (Bourbonnais et al., 1997; Haddadin et al., 2002; Tripathi et al., 2008; Yu et al., 2010b), Oxysporus sp. (Haddadin et al., 2002), Phlebia sp. (Li et al., 2002), Trametes versicolor (Yu et al., 2010b) and Trichoderma reesei (Singh et al., 2008), with reduction of lignin levels ranging from $40 \%$ to $60 \%$. Recent studies have shown that actinomycetes strains (e.g. Aspergillus) can induce lignin degradation levels of up to $92 \%$, with similar culture conditions to those used by basidiomycetes (Singh et al., 2008).

Since carbohydrates are needed for the second stage of biofuel production (i.e. sugar fermentation), the degradation during the delignification stage is a side reaction that affects the yield of biofuel production. Hence, a selection of a microorganism with a low cellulose activity is an important task. Phanerochaete chrysosporium (Shi et al., 2009), Pycnoporus cinnabarinus (Meza et al., 2006), Echinodontium taxodii (Yu et al., 2010b), Euc-1 (Dias et al., 2010), Irpex lacteus (Dias et al., 2010; Yu et al., 2010a), and Pycnoporus sanguineus (Lu et al., 2010), have shown high lignin degradation specificity, while significant levels of 
carbohydrate degradation have been reported for Ceriporiopsis subvermispora (Wan \& Li, 2010), Gleophyllum trabeum (Fissore et al., 2010), Phlebia brevispora (Sharma \& Arora, 2010), Phlebia floridensis (Sharma \& Arora, 2010), Phlebia radiata (Sharma \& Arora, 2010), and Pleurotus sajor-caju (Kannan et al., 1990). This carbohydrates degradation during biodelignification could also depend on the substrate, since fungi with high lignin selectivity can show carbohydrate lost with certain lignocellulosic materials, as observed for paddy straw that presented cellulose lost with all the white-rot fungi used in the delignification (Sharma \& Arora, 2010).

Biodelignification has a direct effect on the availability of sugars for ethanol production, which significantly improves the yield of biofuel production. Although this beneficial effect of delignification is not evaluated in all the studies, the results show that there is no need to produce a $100 \%$ delignification since increases above $20 \%$ in carbohydrates availability can be obtained with just $8 \%$ delignification (Gupta et al., 2010; Shi et al., 2009; Wan \& Li, 2010). In addition, the biodelignification has been used before chemical pretreatments (i.e. alkaline/oxidative or mild alkaline) allowing up to $80 \%$ lignin reduction (Yu et al., 2010a; $\mathrm{Yu}$ et al., 2010b). These results strongly suggest that combination of biological and chemical/physical delignification methods might be a feasible alternative to improves delignification levels and reduces the volume and conditions of the chemical/physical pretreatments, promoting the generation of eco-friendly processes for paper and biofuels companies.

Finally, the use of crude extracts from ligninolytic fungi has shown to be a promissory alternative for delignification. Crude extracts from Aspergillus niger, A. niveus, and A. ochraceus, containging xylanases, allowed a $20 \%$ delignification of cellulase pulp in $2 \mathrm{~h}$ (Betini et al., 2009), while a crude extract of Penicillium oxalicum and Pleurotus osteatus, containg xylanase and laccase enzymes, produced a $21 \%$ delignification of wood pulp in $3 \mathrm{~h}$ (Dwivedi et al., 2010).

\subsection{Bacterial delignification}

Bacteria are less used microorganism in delignification of lignocellulose materials. Most of the studies use Bacillus strains (Table 3), although Cellulomonas and Zymomonas have been recently reported as promissory ligninolytic bacteria (Singh et al., 2008).

The loss of lignin ranges from $8 \%$ to $56 \%$, with similar temperatures and times to those used in fungi-mediated delignification. Bacteria delignification is mainly mediated by extracellular xylanases, although a synergistic effect has been observed by the addition of $\mathrm{MnP}$, pectinase or $\alpha$-L-arabinofuranosidase (Bezalel et al., 1993; Kaur et al., 2010). However, these high lignin removal levels might be accompanied with high levels of cellulose degradation, as observed for B. macerans, C. cartae, C. uda, and Z. mobilis with cellulose reductions ranging from $31 \%$ to $51 \%$. One strategy to overcome this issue is the use of cellulase-free extracts (Kaur et al., 2010) or purified enzymes (Bezalel et al., 1993), that allows up to $20 \%$ delignification levels within shorter incubations times than those observed with the whole microorganisms.

Even though bacteria have shown significant delignification levels, the main application is in the paper industry on pre-bleaching steps or to reduce toxic compounds from paper mill effluents. However, biodelignification has a direct impact in pulp properties, free-sugars, and reduction in effluent toxicity and in the use of chloride compounds (Kaur et al., 2010; Mishra \& Thakur, 2010; Singh et al., 2008). 


\section{Chemical separation of Lignin and carbohydrates}

This section establishes the basis of three types of chemical pretreatment: acidic, alkaline and with solvents. For each, lignin and carbohydrate solubilisation (or degradation) are discussed. It is clear that different types of chemical pretreatments affect biomass differently not only because of differences in the solubilized component (Harmsen et al., 2010), but also because the accessibility attained is different and changes differently as subsequent enzymatic hydrolysis occurs (Kumar \& Wyman, 2009).

A few reports giving meaningful comparisons between different types of chemical pretreatment have been obtained (Wyman et al., 2005a; 2005b; Wyman et al., 2009). A more complete coverage is impractical because different authors present important differences in selected substrates, analytical procedures, and/or method to report results. Abatzoglou et al. (1992) discuss the application of a severity factor or severity parameter to account for the effect of acid on lignocelluloses composition and the extent of reaction if acid pretreatment is used. They state that due to the complexity of reactions, kinetic parameters lack mechanistic meaning and are functions of the ranges of experimental conditions used. Severity factors combine into a single parameter the effect of the different operational variables and have been adapted to other types of chemical pretreatments. One widely adopted defining equation (slightly or importantly modified in some later studies) is as follows:

$$
R_{0}=e^{[(T-100) / 14.5] t}
$$

where $R_{0}$ is the reaction ordinate, $T$ is the pretreatment temperature in ${ }^{\circ} \mathrm{C}$, and $t$ is the pretreatment time in min. $R_{0}$ is meant to provide a zonal indication of the predominant reactions taking place in lignocelluloses. This end result was empirically motivated.

\subsection{Acidic}

Two main configurations of acid pretreatment are diluted and concentrated. During dilute acid pretreatment structural carbohydrates are efficiently solubilized and possibly degraded to an extent that depends on the pretreatment conditions. Here, partial hemicelluloses solubilisation is obtained, therefore increasing pore size. Hydrolysis of the remaining hemicelluloses and cellulose is frequently achieved through a subsequent enzymatic hydrolysis stage that uses enzyme cocktails containing cellulases and xylanases (Mosier et al., 2005; Wyman \& Lloyd, 2005). The acidic reagent may be liquid hot water ( $\mathrm{pH}$ of water decreases with temperature), dilute or concentrated hydrochloric, sulfuric, phosphoric, peracetic, oxalic, and maleic acid among others. Virtually any acid (either mineral or organic) may be used, but sulfuric acid is widely preferred, even though recent studies have shown better hemicelluloses yields with other acids (Lee \& Jeffries, 2011). Pretreatment time (accounted from the moment the biomass reaches the desired pretreatment temperature) ranges between $1 \mathrm{~min}$ and $180 \mathrm{~h}$. Reactor configurations include but are not limited to flowthrough, continuous, and batch. Temperatures range between 25 and $200^{\circ} \mathrm{C}$ at pressures between $1 \mathrm{~atm}$ and $15 \mathrm{~atm}$. Initial acid concentration may range between 0.1 and $6 \%$, more typically between 0.7 and $4 \%$ (Kumar et al., 2009; Sierra et al., 2008). In batch reactors, total pressure corresponds to the saturation pressure of the mixture at the pretreatment temperature. Typically, the highest temperatures require less time and result in a more extensive cellulose degradation. The dilute sulfuric acid pretreatment can achieve high 
reaction rates and significantly improves cellulose hydrolysis (Esteghlalian et al., 1997). Its cost is similar or higher than for other pretreatment options (Eggeman \& Elander, 2005).

Neutralization of $\mathrm{pH}$ is necessary for the downstream enzymatic hydrolysis or fermentation processes. Dilute-acid pretreatment is also known to have a negative influence on the enzymatic hydrolysis of biomass. For example, recent studies report the formation of spherical droplets of lignin and/or lignin and carbohydrate complexes on the cellulose surface. These droplets, preferentially formed at temperatures greater than $130^{\circ} \mathrm{C}$, have an important negative impact on biomass subsequent enzymatic digestibility (Selig et al., 2007). Some other researches argue that materials that have been subjected to acid hydrolysis can be harder to ferment because of the presence of toxic substances including but not limited to furfural and hydroxymethylfurfural (Galbe \& Zacchi, 2002). Furthermore, acid pretreatment results in costly materials of construction, high pressures, neutralization and conditioning of hydrolysate prior to biological steps, slow cellulose digestion by enzymes, and nonproductive binding of enzymes to lignin (Wyman et al., 2005b).

The concentrated acid pretreatment is more widely known as concentrated acid hydrolyisis because it results in complete solubilisation of carbohydrates. Clearly, subsequent enzymatic hydrolysis is not required. This type of pretreatment has a long story (1883 for hydrolysis of cellulose in cotton) with the first industrial plant built in Germany in 1937 using hydrochloric acid. The Arkenol's process, claimed to reduce sugar loss to less than $3 \%$, separating $98 \%$ of the acid (Farone \& Cuzens, 1996), starts mixing lignocelluloses waste (less than $10 \%$ moisture content) with $70 \%-77 \%$ sulfuric acid added at a ratio of 1.25:1 (acid : cellulose+hemicellulose), the temperature is controlled at less than $50^{\circ} \mathrm{C}$. Afterwards, water is added to dilute the acid to $20 \%-30$ and hydrolysis at $100^{\circ} \mathrm{C}$ takes place for an hour. This results in a gel, which is pressed to remove an acid/sugar product stream. Residual solids are subjected to a second hydrolysis step. A chromatographic column is used to separate acid and sugars (Nanguneri \& Hester, 1990). The fermentation converts both the xylose and the glucose to ethanol at theoretical yields of $85 \%$ and $92 \%$, respectively. A triple effect evaporator is required to reconcentrate the acid (Yancey \& Kadam, 1997).

The industrially used concentrated pretreatment must not be confused with the complete solubilisation of carbohydrates widely used for quantification of structural lignin and carbohydrates. The corresponding protocol uses sulfuric acid reagent in two stages, one concentrated at mild temperature $\left(72 \% \mathrm{w} / \mathrm{w}, 30^{\circ} \mathrm{C}\right)$ and the other diluted at high temperature $\left(4 \% \mathrm{w} / \mathrm{w}, 121^{\circ} \mathrm{C}\right)$ (Sluiter et al., 2004).

\subsubsection{Reactions during acid pretreatment}

During acid pretreatment a rather severe solubilisation (and some degradation of monomers) of hemicelluloses occur. Concurrently, a change in the lignin structure takes place. Wood lignin submitted to diluted acid pretreatment (Sannigrahi et al., 2008), as well as wood submitted to steam explosion ( $\mathrm{Li}$ et al., 2007), and switchgrass submitted to diluted acid pretreatment (Pingali et al., 2010) presented a decrease in the $\beta-\mathrm{O}-4$ linkages in lignin, which are fragmented during high temperature acid-catalyzed reactions. The extent at which these reactions occur is illustrated in Fig. 5 (Li et al., 2007). Other effects of acid pretreatment on the structure of wood lignin include a decrease in the protonated and oxygenated aromatic carbons per aromatic ring (Sannigrahi et al., 2008).

As a result of the substantial cleavage of $\beta-\mathrm{O}-4$ linkages, the molecular weight distribution of lignin would be expected to decrease; however, this is not the case. A comprehensive repolymerization (condensation reactions) resulting in an increase in molecular size and a 
more heterogeneous lignin structure is obtained (Li et al., 2007) (Fig. 6). The simultaneous depolymerization and repolymerization of lignin during an acid pretreatment are undesirable reactions since they will lead to an increase in the heterogeneity of the resulting lignin. In addition, solubility and reactivity properties will be negatively affected. Reactions, shifting the $\mathrm{pH}$-conditions of the steam treatment towards the alkaline side could be one way to reduce the formation of carbonium ions and inhibit severe structural changes in the lignin polymer. Alternatively, the addition of inhibitors for the repolimerization reactions (i.e., reactive phenol, 2-naphthol ( $\mathrm{Li}$ et al., 2007)) lead to an important delignification with the production of lignin with uniform structure.
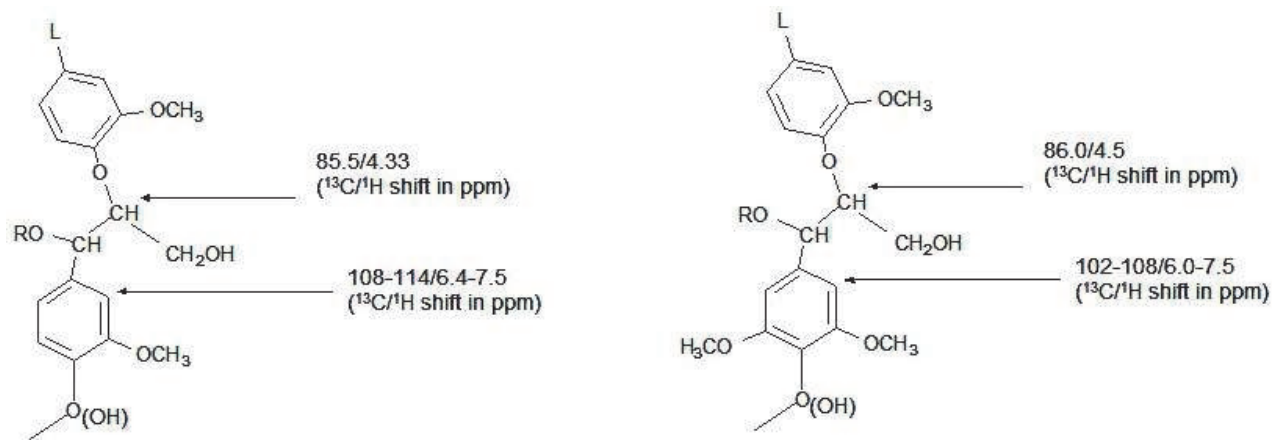

Fig. 5. The $\beta-\mathrm{O}-4$ structure in lignin together with ${ }^{13} \mathrm{C} /{ }^{1} \mathrm{H}$ shift values for $\mathrm{CH}$-groups.
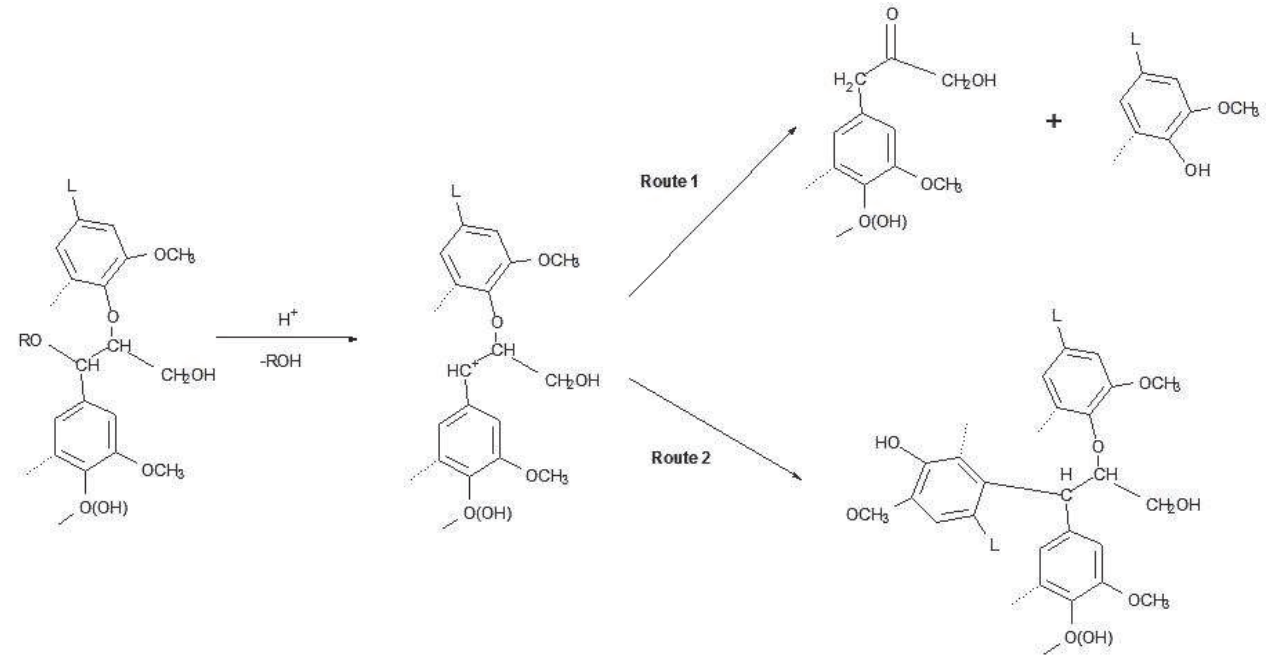

Fig. 6. Competition between depolimerization (route 1) and repolimerization (route 2) reactions in lignin during acid pretreatment (Li et al., 2007).

On the other hand, depolymerization of polysaccharides resulting from steam treatment through cleavage of glucosidic linkages is desirable for conversion of carbohydrates through fermentation processes. However, if monomeric carbohydrates are further degraded into 
HMF (from hexoses) and furfural (from pentoses), a true yield loss occurs. Maximum loss of glucose and xylose in HFM and furfural formation have been reported as $\sim 35 \%$ and $\sim 5 \%$ of original content respectively depending on pretreatment conditions (Farone \& Cuzens, 1996). While the carbohydrate content decreases following pretreatment, the proportion of hexose sugars within the carbohydrate fraction increases. Li et al ( $\mathrm{Li}$ et al., 2005) reported that only about half this fraction was true lignin while the rest comprised "pseudo-lignin" material. This lignin like material is formed by dehydration and repolymerization of polysaccharide degradation products such as furfural, which are formed during high temperature pretreatments.

The discussion presented here is not comprehensive but only fundamental. The presence of products from lignin, glucose and xylose degradation reactions including but not limited to organic acids, phenols and aromatic aldehydes (Chen et al., 2006) is an indication of this fact. In depth studies to elucidate the mechanisms through which these reactions occur is important because all of the degradation products are inhibitors of fermentation and result in an undesired carbohydrates yield loss.

\subsubsection{Kinetic modeling acid pretreatment}

As discussed in the previous section, all of the main cell wall constituents of lignocelluloses react during acid pretreatment. However, kinetic studies are not available for lignin reactions. The main focus of kinetic modeling work has been hemicelluloses hydrolysis with its consequent degradation. Because xylose is often the main constituent in hemicelluloses, comprising up to $90 \%$ of the total hemicellulose dry weight depending on the feedstock (McMillan, 1992), hemicelluloses degradation modeling only accounts for the production of xylose monomers. Three main mechanisms have been proposed and are depicted in Fig. 7. The most adapted mechanism (Fig. $7 \mathrm{~b}$ ) uses a four-step pseudo-first-order irreversible reactions with Arrhenius type constants.

(a)

$$
\begin{aligned}
& \text { Hemicellulose } \\
& (\mathrm{HX})
\end{aligned}
$$

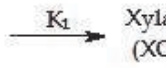

XYlan

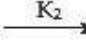

Xylose

(X)

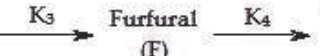

(F)

Degradation Products

(D) (b)

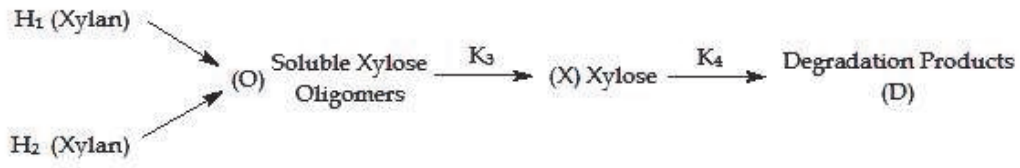

$$
S=\sum_{i=1}^{N} v_{i} S_{i} \rightarrow \sum_{i=1}^{N} \sum_{j=1}^{M(i)} v_{j i} P_{j i}
$$

Fig. 7. Mechanisms for degradation of hemicelluloses during acid pretreatment. (a) Accounts for the formation of furfural and from there other degradation products (Morinelly et al., 2009) (b) Accounts for different hemicelluloses hydrolysis reactivities (fast and slow)(Chen et al., 1996; Esteghlalian et al., 1997; Grohmann et al., 1985; Lee et al., 2000; Schell et al., 2003) (c) lumped system approach. A reaction system $(S)$ is composed of $N$ subsystems producing $M$ final products $P$. The reaction stoichiometric coefficients are $v$ (Abatzoglou et al., 1992). 
Some work also accounts for cellulose degradation reactions as shown in the following equation (Lee et al., 2000):

$$
\text { Cellulose } \stackrel{\mathrm{k}_{1}}{\longrightarrow} \text { Glucan } \stackrel{\mathrm{k}_{2}}{\longrightarrow} \text { Glucose } \stackrel{\mathrm{k}_{3}}{\longrightarrow} \text { Degradatio } \mathrm{n} \text { products }
$$

Rate equations are then obtained for the different reactors and reactions considered. For example, for reactions in Fig. 7a the equations are:

$$
\frac{d X H(t)}{d t}=-k_{1} X H(t) ; \frac{d X O(t)}{d t}=-k_{1} X H(t)-k_{2} X O(t) ; \frac{d X(t)}{d t}=-k_{2} X O(t)-k_{3} X(t) ; \frac{d F(t)}{d t}=-k_{3} X(t)-k_{4} F(t)
$$

For models in Fig. $7 \mathrm{~b}$, reported activation energies in $k_{1}$ and $k_{2}$ varied between 50 and $250 \mathrm{~kJ}$ $\mathrm{kmol}^{-1}$ depending on the reactor employed and the feedstock used. The highest values were reported for continuous reactors at pilot plant scale using corn stover (Schell et al., 2003) and the lowest for wheat straw in a batch reactor (Grohmann et al., 1985). High activation energies may serve as an indication that the system follows a chemical reaction-limited kinetics rather than a mass transport limited kinetics. Some interesting conclusions from the diverse dilute sulfuric acid kinetic studies are: (i) xylose yields are favored at high temperatures and short times (Chen et al., 1996; Esteghlalian et al., 1997; Grohmann et al., 1985; Lee et al., 2000; Morinelly et al., 2009; Schell et al., 2003); (ii) selectivity defined in terms of either Arrhenius constants ratios or activation energies ratios shows that high temperatures have an enhancing effect on the hemicelluloses breakdown to oligomers (i.e., in Fig. $7 \mathrm{a}, E_{1} / E_{2}>1$ ), however, the hydrolysis of oligomers is less favored than the formation of degradation products (i.e., in Fig 7a, $E_{2} / E_{3}<1$ ) (Morinelly et al., 2009); (iii) high solids concentration is desirable because in addition to help the process economics, less degradation of xylose to furfural is obtained, and these solids act as a barrier that protects monomers from degradation, though the main drawback of is slow reaction rates (Morinelly et al., 2009); (iv) total carbohydrates yields are lower at pilot scale than they are in laboratory scale, demonstrating the importance of pilot plant scale measurements in the scaling up of the process (Schell et al., 2003); (v) countercurrent shrinking bed reactors result in solubilisation of both cellulose and hemicellulase, but selectivity of desired monomers is better than with other reactors because of lower residence times (Lee et al., 2000); and (vi) no direct comparisons among different studies can be made due to important differences in reaction conditions.

\subsection{Alkaline}

Alkali delignification of lignocellulosic biomass is widely applied at industrial scale. The process is known as soda and kraft pulping and its chemistry has been extensively discussed (Alen, 2000; Klinke et al., 2002; Sjöström, 1981). Frequently, an oxidative agent is applied at high temperatures obtaining an important enhancement of the pretreatment effects. Sodium, potassium, calcium, and ammonium hydroxides are suitable for this type of pretreatment. Among these, calcium hydroxide is the least expensive and can be easily regenerated using the lime Kiln technology; however, at industrial scale, sodium hydroxide is widely preferred (Sanchez, 2007). Lime pretreatment has proven to be a useful method for selectively reducing the lignin content of lignocellulosic biomass without significant loss in carbohydrates, thus realizing an important increase in biodigestibility (Chang et al., 1997; Kim \& Holtzapple, 2005; Sierra, 2005; Sierra et al., 2009a; 2009b). With ammonium 
hydroxide two main processes have been developed: Ammonia Freeze Explosion (AFEX) and Ammonia Recycle Percolation (ARP). In AFEX, biomass is mixed with liquid ammonia and then treated at high-pressure. When pretreatment time is elapsed, the pressure is suddenly released. The combined chemical and physical effects of this pretreatment increase lignocelluloses pore size making it digestible (Shao et al., 2010). There are many adjustable parameters in the AFEX process: ammonia loading, water loading, temperature, time, blow down pressure, and number of treatments (Holtzapple et al., 1991). In ARP the biomass is pretreated with aqueous ammonia in a flow-through column reactor. The liquid flows at high temperature through the reactor column, which has been previously packed with biomass. To prevent flash evaporation the reactor system must be slightly pressurized (Kim et al., 2003). After reaction the solid fraction, rich in cellulose and hemicellulose, is separated from the liquid.

Another pretreatment ranked within this category is referred to as wet alkaline oxidation or catalytic wet oxidation. The alkali agents reported are $\mathrm{NaOH}$ and $\mathrm{Na}_{2} \mathrm{CO}_{3}$. This is not to be confused with wet oxidation pretreatment which does not use an alkali. The oxidative agent may be oxygen, air, or hydrogen peroxide (Klinke et al., 2002). Alkaline wet oxidation uses temperatures above $180^{\circ} \mathrm{C}$, pressures in the range $1.4-1.6 \mathrm{MPa}$, and reaction times up to 30 $\min$.

\subsubsection{Reactions during alkaline pretreatment}

The major effect of alkaline pretreatment is delignification. Alkaline pretreatments successfully increase lignocelluloses digestibility without the production of furfural and methylfurfural (Harmsen et al., 2010; Sierra et al., 2008). Concurrently, acetyl removal is obtained, which is advantageous because acetyl groups inhibit fermentation (Wyman et al., 2009). Alkaline hydrolysis mechanism is based on saponification of intermolecular ester bonds crosslinking xylan hemicelluloses and lignin (Sun \& Cheng, 2002).

Although lignin degradation has been the subject of much study over many years, it is far from being completely understood. Complete biomass delignification is difficult because of its location within the deep cell wall, hydrophobicity, physical stiffness, strong polyring bonds of C-O-C, C-C, and the tendency of recondensation (Kim et al., 2003). Fortunately, complete delignification is not required to make biomass fully digestible (Sierra et al., 2009b; Sierra et al., 2010).

Alkaline depolymerization of lignin mostly depends on the cleavage of two types of aryl ether bonds: $\mathrm{C}_{\text {aliphatic }}-\mathrm{O}-\mathrm{C}_{\text {aromatic }}$ and $\mathrm{C}_{\text {aromatic }}-\mathrm{O}-\mathrm{C}_{\text {aromatic }}$ (ordered from least to most stable), which frequently correspond to $\alpha$ - and $\beta$-aryl ether bonds (50-70\% in wood). Examples of these typical delignification reactions (only $\mathrm{OH}^{-}$anions involved) are presented in Fig. 8. Oxidative agents importantly enhance the effects of alkaline pretreatments. Oxygen is relatively unreactive; however, in alkaline media it is reduced through the reaction with phenolic hydroxyl groups to superoxide radical $\left(-\mathrm{O}_{2} \bullet\right)$. The production of these groups requires very basic conditions $(\mathrm{pH}>12)$. Reactions involved in alkaline oxidative pretreatments are primarily single-electron (radical) reactions. Delignification reactions involve the formation of several different acids that introduce hydrophilic groups into the lignin structure. Nucleophilic attack also occurs in some extend causing ring opening, which promotes further degradation and solubilization. Condensation products may leave remaining lignin unreactive in the oxidative alkaline media. 
Because lignin fractions contain reactive groups, undesirable condensation reactions may occur between lignin entities retarding delignification. This is known to occur mostly in terminal phases of delignification processes and at the unoccupied C-5 position of phenolic units (Sjöström, 1981).
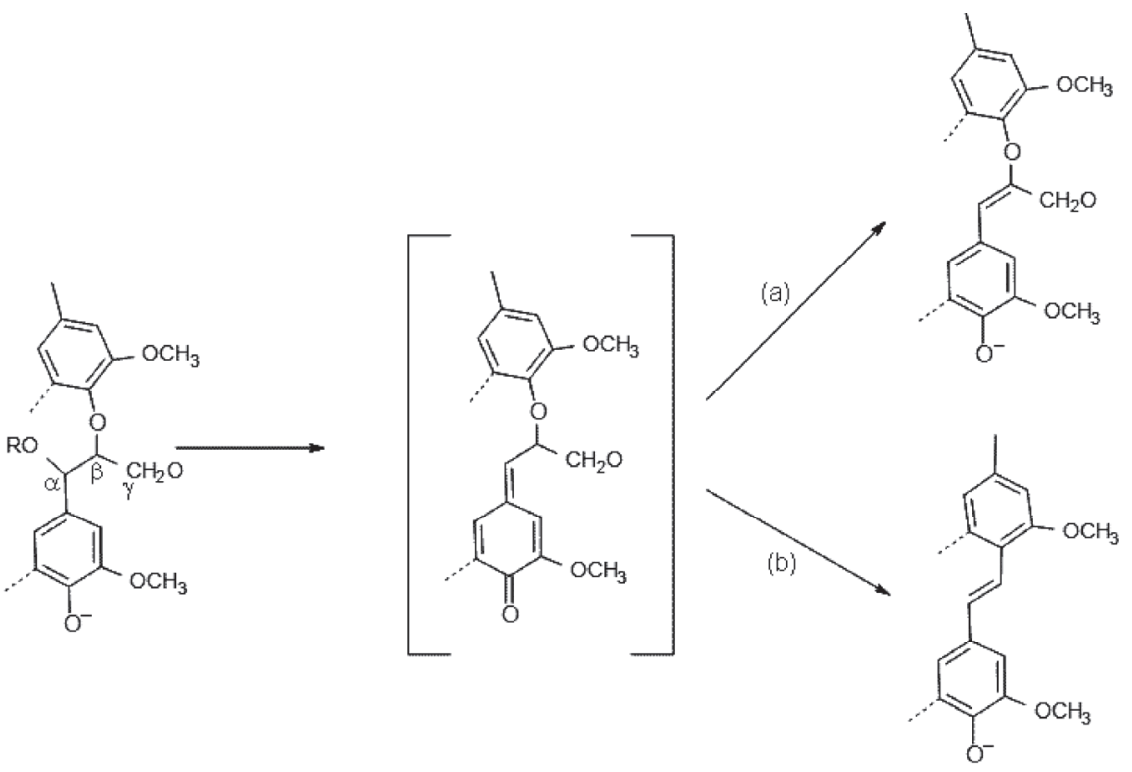<smiles>COc1cc(C)ccc1[O-]</smiles><smiles>COc1cc(C)ccc1[O-]</smiles><smiles>COc1cc(C)cc(Cc2cc(C)cc(OC)c2[O-])c1[O-]</smiles><smiles>COc1cc(C)ccc1[O-]</smiles><smiles>COC1=CC(C)=CC(C)C1=O</smiles><smiles>COc1cc(C)cc(C(=O)O)c1</smiles>

Fig. 8. Lignin degradation reactions in alkaline conditions involving $\alpha$ - and $\beta$-aryl ether linkages (a) cleavage of $\alpha$-aryl ether linkage (b) cleavage of $\mathrm{CH}_{2} \mathrm{O}$ group (c) example of a possible condensation reaction. (d) Example of alkaline oxygen degradation of lignin (Gierer \& Stockholm, 1985; Guay, 2000).

Unfortunately, alkaline delignification is not completely selective. A fraction of carbohydrates in the presence of alkali and oxygen undergo both oxidation and alkaline degradation generating a complex mixture of products. A wide variety of organic acids are produced as a result of carbohydrates degradation during alkaline pretreatment (Klinke et al., 2002). Due to this fact, an important decrease in $\mathrm{pH}$ may take place during pretreatment, particularly if initial alkali concentration is not high. If pretreatment starts with a high initial 
alkali concentration, $\mathrm{pH}$ is approximately constant and first order reaction rates of cellobiose degradation are obtained (Bonn et al., 1985).

\subsubsection{Kinetic modeling alkaline pretreatment}

Kinetic models applied to oxygen bleaching of paper pulp focus on the degradation of polymers, either lignin or carbohydrates. Even though there is complex modeling (Kopelman, 1988), most models separate different moieties that degrade at three different rates: rapid, medium, and slow (de Groot et al., 1994; Susilo \& Bennington, 2007). These models were successfully applied to lignin and carbohydrate degradation of lime pretreatment of sugar cane bagasse (Granda, 2005), corn stover (Kim \& Holtzapple, 2006), and poplar wood (Sierra et al., 2011a; Sierra et al., 2011b).

Two parallel, first-order reactions accurately represent delignification and carbohydrate degradation. They consider differing reactivities for each biomass component (lignin, cellulose, and hemicellulose). This model successfully represents literature data (Sierra et al., 2011a).

$$
-\frac{d Y_{i}}{d t}=k_{i f} M_{O_{2}}^{\beta i f} Y_{i f}+k_{i s} M_{O_{2}}^{\beta i s} Y_{i s}
$$

Where

$$
k_{i j}=a_{i j} \exp \left(-\frac{E_{i j}}{R T}\right)
$$

and

$$
\begin{aligned}
& k^{i j}=\quad \text { rate constant for component } i(L, G \circ X) \text { and moiety } j(f, s)\left(\min ^{-1}\right) \\
& a^{i j}=\quad \text { frequency factor for component } i(L, G \circ X) \text { and moiety } j(f, s)\left(\mathrm{min}^{-1}\right) \\
& E_{i j}=\quad \text { activation energy for component } i(L, G \circ X) \text { and moiety } j(f, s)(\mathrm{kJ} / \mathrm{mol}) \\
& R=\quad \text { ideal gas constant }\left(8.314 \times 10^{-3} \mathrm{~kJ} /(\mathrm{mol} \cdot \mathrm{K})\right) \\
& T=\quad \text { absolute temperature }(\mathrm{K}) \\
& M^{O 2}=\quad \text { initial oxygen charge ( } \mathrm{kg} \text { initial oxygen } / \mathrm{kg} \text { initial dry biomass) } \\
& \beta^{j j}=\quad \text { exponent for component } i(L, G \circ X) \text { and moiety } j(f, s) \text { (dimensionless) }
\end{aligned}
$$

The models allow the calculation of selectivity, defined for glucan with equation 6. Glucan and xylan selectivity measure the ability of pretreatment to remove lignin while retaining carbohydrates.

$$
S_{d G} \equiv \frac{d Y_{L} / d t}{d Y_{G} / d t}=\frac{a_{L f} \exp \left(-\frac{E_{L f}}{R T}\right) M_{O 2}^{\beta L f} Y_{L f}+a_{L s} \exp \left(-\frac{E_{L s}}{R T}\right) M_{O 2}^{\beta L s} Y_{L s}}{a_{G f} \exp \left(-\frac{E_{G f}}{R T}\right) M_{O 2}{ }^{\beta G f} Y_{G f}+a_{G s} \exp \left(-\frac{E_{G s}}{R T}\right) M_{O 2}{ }^{\beta G s} Y_{G s}}
$$

Using this definition it is possible to calculate the pretreatment conditions that result in a desired biomass composition. 


\subsection{Organosolv}

Organosolv pretreatment is similar to organosolv pulping. The main purpose is lignin separation from the carbohydrates matrix. This pretreatment is effective removing biomass recalcitrance because it achieves almost complete separation of biomass components (Zhao et al., 2009). Three separate fractions are obtained: solid lignin, an aqueous stream, and high purity cellulose. Lignin is recovered unaltered; thus, it has high potential for other applications. In the aqueous phase hemicelluloses are either hydrolysed to xylose monomers or degraded (Johanson et al., 1987).

Some of the most commonly used solvents are low boiling point methanol, ethanol, and acetone. Both alcohols are low cost and miscible in water. At $180{ }^{\circ} \mathrm{C}$, the addition of a catalyst is required (at $\sim 0.2 \%$ concentration). Both mineral acids (i.e., hydrochloric, sulfuric and phosphoric) and organic acids (i.e., formic, oxalic, acetylsalicylic, and salicylic) may be used as catalysts to accelerate delignification and xylan degradation (Zhao et al., 2009); however, acids are not required if the pretreatment is conducted at temperatures in the range 190 to $210{ }^{\circ} \mathrm{C}$ because liquid hot water is acidic (Duf \& Murray, 1996). In alcohol organosolv, the solvent concentration is $50-80 \%$ with the highest concentration for hard to pretreat biomass. Usually, pretreatment temperatures for methanol are lower than for ethanol, but ethanol is safer due to its lower toxicity. The Lignol technology uses ethanol as solvent and converts a range of cellulosic feedstocks into several valuable organic chemicals and fuels (Arato et al., 2005). Using low boiling point solvents, such as ethanol, methanol and acetone, organosolv pretreatment requires high pressures because pretreatment runs at high temperatures. To perform at atmospheric pressure, a variety of high boiling point alcohols may be used including but not limited to ethylene glycol, glycerol, and tetrahydrofurfuryl. Organosolv pretreatment with low boiling point alcohols has successfully run at $240{ }^{\circ} \mathrm{C}$ for $4 \mathrm{~h}$. Drawbacks include high-energy consumption for solvents recovery and high costs of solvents (Aziz and Sarkanen 1989).

Other kind of organic compounds such as formic, acetic, and peracetic acids, dimethylsulfoxide, ethers, ketone, and phenols are widely used (Thring et al., 1990). When the solvents are organic acids, subsequent enzymatic hydrolysis may not be as successful as with other solvents, probably due to inhibition caused by acetyl groups (Pan et al., 2006). If peracetic acid is used, pretreatment can be conducted at ambient or mild temperatures (e.g., $80^{\circ} \mathrm{C}$ ) for long times and the addition of $\mathrm{NaOH}$ may cause biomass swelling. Compared to acid and alkaline pretreatment at the same conditions, peracetic acid is more effective (Zhao et al., 2008).

Due to important advantages obtained through efficient separation of components, organosolv pre-treatments are the most promising options for a biorefinery. Nevertheless, these type of pre-treatments are still very undeveloped because they require extensive and cumbersome washing steps in order to obtain complete solvents removal, and they are energy intensive if high solvents recovery is to be achieved (Zhao et al., 2009). Removal of solvents is not only required for the process economics but also because their presence may be inhibitory for enzymatic hydrolysis and fermentation (Holtzapple \& Humphrey, 1984). If high pressures must be applied, the equipment costs increase substantially.

\subsubsection{Reactions during organosolv pretreatment}

In organosolv pretreatment, the reactions that take place highly depend on the solvent choice. For example, if alcohols are used, $\mathrm{OH}^{-}$attacks the lignin-hemicellulose acid ester 
bonds at the $\alpha$ carbons of the lignin monomers as well as the ether and 4-Omethylglucoronic bonds. Of these, cleavages of ether linkages are primarily responsible for lignin breakdown. Also, hydrolysis of the glycosidic bonds in hemicelluloses occurs. If an acid catalyst is employed, degradation of lignin and monosaccharides may happen (Chum et al., 1990).

On the other hand, if peracetic acid is used, the hydroxonium ion is present $\left(\mathrm{OH}^{+}\right)$generated from peracetic acid in acidic media. This ion attacks lignin by ring hydroxylation. Peracetic acid is a powerful oxidizing agent; thus, oxidative demethylation and ring opening may occur. Other reactions are displacement of side chains and cleavage of $\beta$-arylether bonds.

\section{Biotransformation of lignocellulosic material into alternative fuels}

The main interest in the use of agro-industrial by-products and agro-waste streams is the release of the fermentable carbohydrates contained into the lignocellulosic matrix. The cost of lignocellulosic feedstocks is currently appealing because it is lower than any other energy sources. For example, crude oil price ranges from $\$ 40$ to $\$ 80$ per barrel, generating an energy price that ranges from $\$ 7.1$ to $\$ 14.2 \mathrm{GJ}^{-1}$, while the energy price from lignocellulosic ranges from $\$ 0$ to $\$ 3 \mathrm{GJ}^{-1}$ (Zhang, 2008). Nevertheless, the actual cost of fuel production from lignocellulosic feedstock can be higher than conventional processes (e.g. ethanol from sugarcane or corn) generating an expensive fuel (Ferris \& Joshi, 2010). This can be caused by increased lignocelluloses prices due to higher demand, biomass conditioning and transportation costs, and the cost and yields of the different process stages like pretreatment, saccharification, detoxification and fermentation (Aden et al., 2002). The National Renewable Energy Laboratory (NREL), in its economical evaluation of biotransforming corn stover to ethanol in a plant that uses simultaneous saccharification and fermentation technology, calculated an ethanol selling price close to $\$ 1.07$ per gallon $(+\$ 0.12 /-\$ 0.05)$ in a plant with an installed capacity of 2000 metric tons of lignocellulose per day. They considered the total project investment, the variable operating cost and fixed operating cost for a plant life of 20 years and an ethanol production of 69.5 millions of gallons per year. They showed that the most expensive item in the process is the feedstock cost followed by the pretreatment cost. Further details can be consulted in the NREL report (Aden et al., 2002). Technological alternatives to Simultaneous Saccharification and Fermentation may even result in more favorable prices.

Transformation of highly oxygenated compounds like carbohydrates allows the production of alcohols, carboxylic acids, and esters. Compounds like fragrances solvents, and lubricants may be produced from lignocellulosic feedstocks, and bio-polymers such as polylactic acid and poly(trimethylene terephthalate) that use lactic acid and 1,3-propanediol as precursors, respectively, can be obtained through carbohydrates fermentations (Ragauskas et al., 2006). Among the different chemical compounds that can be used as fuels, alcohols are of a particular interest due to characteristics like a high octane number, broad flammability limits, high flame speeds, and high vaporization heats. These properties have allowed blending ethanol, one of the most important alcohols, with gasoline in mixtures that contain up to $85 \%$ ethanol (E85)(Turner et al., 2011). Currently, ethanol and methanol are the most important alcohols used in internal engine combustion. Although these alcohols are obtained after fermentation of the free sugars that result from the depolymerization of carbohydrate polymers, alcohols also can be obtained by direct fermentation of the released 
carbohydrate polymers. Fig. 9 summarizes the process stages in the widely studied Simultaneous Saccharification and Fermentation Technology.

During pretreatment toxic compounds are released in a concentration that may vary widely. These compounds have been grouped in four categories: (i) sugar degradation products, (ii) lignin degradation products, (iii) compounds derived from cellulose structure, and (iv) heavy metal ions released by corrosion of the hydrolysis equipments. These compounds include but are not limited to furfural and hydroxymethyl furfural formed by the degradation of pentoses and hexoses; acetic, formic, galacturonic and glucuronic acids formed during the hydrolysis of hemicellulose; and aromatic and phenolic compounds, like cinnamaldehyde, p-hydroxybenzaldehyde, and syringaldehyde (Cardona et al., 2010; Mussatto \& Roberto, 2004; Sánchez \& Cardona, 2008).

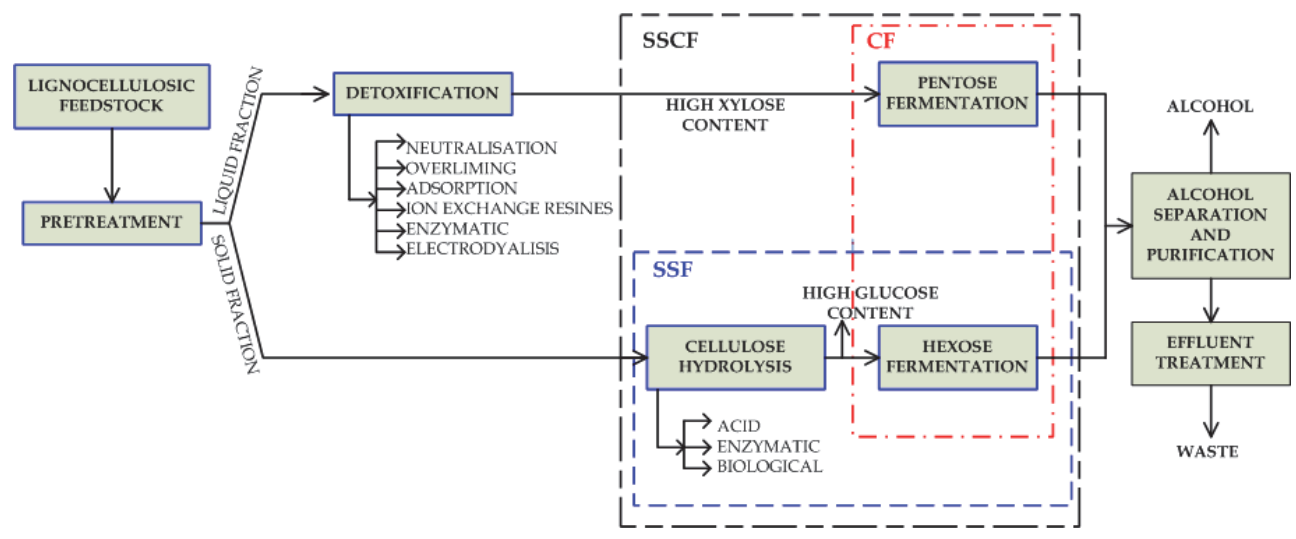

Fig. 9. Process scheme of the lignocellulosic biomass transformation to liquid fuels, mainly alcohols. SSF: simultaneous saccharification and fermentation, CF: co-fermentation, and SSCF: simultaneous saccharification and co-fermentation (Adapted from Cardona et al. (2010))

The detoxification stage, in which most of the inhibitory compounds formed in the pretreatment stage are removed, is important for the further fermentation stage. This process can be conducted by physical and chemical or biological means. The biological detoxification (BD) may be advantageous because of minimal generation of waste streams, chemical inputs are not required, possible recharging of adsorption resins is not needed, and it is suitable for solid-liquid mixtures (Nichols et al., 2010). The participation of peroxidases and laccases in BD processes has been evaluated. Lacasses have completely removed phenol compounds of low molecular weight by an oxidative polymerization mechanism without varying the acetic acid and furans composition in the hydrolyzate (Chandel et al., 2007). The use of microorganisms like the fungi Thrichoderma reesei and Aspergillus nidulas to remove acetic and formic acids, furfural and hydroxymethyl furfural, and acid benzoic derivatives has been also reported (Palmqvist \& Hahn-Hägerdal, 2000; Yu et al., 2011). Finally, another important but not widely reported method is the adaptation of microorganisms to the hydrolyzate. This method is based in the re-use of the microorganism in successive hydrolizate treatments where the microorganism of one assay is used as inoculum for the next one (Silva \& Roberto, 2001). Classical physical-chemical processes are based on toxic compound precipitation, adsorption onto charcoal, diatomaceous earth, ion-exchange resins, 
and $\mathrm{pH}$ adjustment of the extractive (Mussatto \& Roberto, 2004). Moroever, new alternatives that use membranes have emerged. One example is the use of reactive membrane extraction in which is avoid the dispersion of one phase in the other reducing the presence of organic compounds, or solvents, in the aqueous phase or hydrolyzate (Simonne et al., 1997).

Carbohydrates depolymerization widely known as hydrolysis or saccharification is carried out by using cellulolytic enzymes complexes constituted by endoglucanases, exoglucanases or cellobiohydrolases, and cellobiases (Bansal et al., 2009; Lee, 1997). Endoglucanases (EC 3.2.1.4, endo-1,4-D-glucanohydrolase) create free chain-ends attacking low crystallinity regions in the cellulose fiber by cleaving $\alpha-1,4$-glycosidic bonds. Exoglucanases (EC 3.2.1.91, 1,4-b-D-glucan cellobiohydrolase) remove cellobiose units from the free chain-ends providing a further hydrolysis of the molecule. Finally, the cellobiase or $\beta$-glucosidase (EC 3.2.1.21) hydrolyses the cellobiose to glucose. Bansal et al. (2009) reviewed the mechanism and mathematical modelling of cellulose hydrolysis by cellulases where the mechanism main steps are: (i) cellulose adsorption onto the substrate via the binding domain, (ii) location of a suitable bond to hydrolysis on the substrate surface, usually the end of the chain or cleavable bond if cellobiohydrolase or endoglucanase is presented, respectively, (iii) formation of enzyme-substrate complex to initiate hydrolysis, (iv) hydrolysis of the $\alpha$ glycosidic bond and simultaneous forward sliding of the enzyme along the cellulose chain, (v) desorption of cellulases from the substrate or repetition of step iv or steps ii and iii if the catalytic domain detaches from chain, vi) hydrolysis of cellobiose to glucose if $\alpha$ glucosidase. The main product of the cellulose hydrolysis is glucose, which can be further fermented or chemically transformed. In this stage, the most important parameters to be controlled are reaction time, temperature, $\mathrm{pH}$, enzyme dosage and substrate load (Sánchez \& Cardona, 2008).

The last biological stage is fermentation. Streams from the detoxification and/or saccharification stages have a high xylose and glucose concentration. These sugars might be bio-converted to fuels by several microorganisms, including Candida albicans, Candida shehatae, Kluveromyces fragilis, Kluveromyces marxianus, Pichia stipitis, Saccharomyces cerevisiae, Bacillus subtilis, Bacillus stearothermophilus, Clostridium cellulolyticum, Clostridium beijerinckii, Escherichia coli, and Zymomonas mobilis, which can produce compounds like ethanol, glycerol, butanol, and acetate, among others depending on their metabolic networks. Nevertheless, important differences in the metabolic transformation of xylose a C-5 carbohydrate and glucose a C- 6 carbohydrate between bacteria and fungi cause that not all native microorganisms are capable of metabolizing both carbohydrates to ethanol.

It is known that bacteria can transform xylose to xylulose by using xylose isomerase, while most yeasts, fungi, plants, and animals use aldose (xylose) reductase and xylitol dehydrogenase with xylitol as an intermediate (Chiang \& Knight, 1960 ). Nevertheless, if the first reaction step uses NADPH as a cofactor, the reaction is tied to NADPH production, with a subsequent $\mathrm{NAD}^{+}$reduction, which can cause a cofactor imbalance under oxygen limitation (Bruinenberg et al., 1983). For example, Toivari (2004) reported an endogenous xylose metabolic pathway in Saccharomyces cerevisiae which in aerobic conditions generated a xylitol accumulation into cells caused by lack of $\mathrm{NAD}^{+}$, but when xylitol is released to the medium the ethanol production yield decreases (Eliasson et al., 2000; Eliasson et al., 2001). Due to these metabolic drawbacks, genetically modified microorganisms capable to ferment both C-5 and C- 6 carbohydrates are the focus of attention to improve ethanol production yields. Extensive literature use $S$. cerevisiae as biological model due to its tolerance to media 
up to $20 \% \mathrm{v} / \mathrm{v}$ in ethanol among other toxic compounds released during its growth. Also, Z. mobilis is amply considered since it has been genetically modified to obtain ethanol by cofermentation of several substrates like glucose, xylose and arabinose. This topics have been reviewed elsewhere (Kambam \& Henson, 2010; Vinuselvi et al., 2011).

For the production of liquid biofuels, mainly ethanol, sequential or simultaneous operational configurations between the hydrolysis or saccharification and fermentation stages have been adopted. Simultaneous saccharification-fermentation (SSF) processes present better ethanol production yields and less energy consumption than sequential hydrolysis-fermentation (SHF) (Sánchez \& Cardona, 2008), fermentation time is shorter than SHF, contamination risk with external microorganism is reduced, and presents an important cost reduction since cellulose hydrolysis occurs during glucose fermentation that decreases the inhibition caused by sugars on cellulases. The most important disadvantages of SSF are the difference of optimal temperature for the hydrolysis $\left(45-50^{\circ} \mathrm{C}\right)$ and fermentation $(28$ $35^{\circ} \mathrm{C}$ ) stages, the inhibition of the fermenting microorganism and even the cellulose activity caused by the ethanol and the toxic compounds than can be eventually produced during the lignocellulosic biomass pretreatment, and low final concentration of products due to the use of dilute media to obtain suitable rheological properties (Sánchez \& Cardona, 2008; Szczodrak \& Fiedurek, 1996). The most important advantage of SHF is that hydrolysis and fermentation stages can be carried out at their optimal condition.

The search of new strains or genetically engineered strains that can produce ethanol from xylose allows that through independent fermentations (co-fermentation, CF) of pentoses and hexoses, the ethanol production yield increases (Fig. 9). Nevertheless, the fact that most of the genetically engineered strains to metabolize xylose produce ethanol from glucose has risen in the inclusion of the co-fermentation process to the SSF, which is known as simultaneous saccharification and co-fermentation (SSCF) (Fig. 9). This configuration integrates in only one unit the hydrolysis of cellulose and the fermentation of pentoses. Although economical benefits are evident by using $\mathrm{CF}$ and SSCF, challenges emerge because most of xylose-fermenting yeasts (XFY) are not ethanol tolerant; thus, they are prompt to inhibition. New ethanol-tolerant strains should be selected for the CF process, otherwise, joining ethanol removal processes to the SSCF process can help incrementing the ethanol production yield (Chen, 2010).

The direct microbial conversion (DMC) of lignocellulosic biomass to ethanol has also been studied. In DMC, the biodelignification, hydrolysis, and fermentation are done in the same process unit by either one microorganism or a consortium of microorganisms. DMC seems to be an economical process since all the necessary stages for lignocellulosic bioconversion are interconnected. Nevertheless, DMC are slow, and undesired by-products mainly acetic and lactic acids may result when bacteria are used. Another obstacle in DMC is that hydrolysis products such as glucose and cellobiose, can cause inhibition of the cellulase complex limiting the rate of saccharification and final concentration of sugars which result in low ethanol production yields (Mielenz, 2001; Szczodrak \& Fiedurek, 1996).

Although most of alternative fuel investigations have focused on biotechnology processes, mainly ethanol production, other chemical compounds of interest useful as fuel, like esters hydrogen, and hydrocarbons can be obtained. In addition, chemical technologies have been rising up as a feasible alternative in which the main goal is to obtain oxygenated hydrocarbons, by removing oxygen from carbohydrates, which can be subsequently transformed to an alternative fuel (Ragauskas et al., 2006). 
Despite the fact that biological agents can be involved in all the lignocellulosic transformation stages, few processes employ biological agents in all the stages. More commonly, a combination of biological, chemical, and thermo-chemical processes is employed along the different stages. This results in the production of methanol, butanol, hydrogen, and methane, as important fuel alternatives. Methanol production can be accomplished by (i) biochemical conversion of sugars, (ii) thermo-chemical conversion of biomass by using heat energy and chemical catalyst, (iii) production of syngas from biomass gasification at high temperature and an oxygen-starved environment, and (iv) biomass pyrolysis at high temperature under an oxygen-free environment (Dolan, 2010). Hydrogen production from biomass can be achieved by (i) syngas production and its later transformation by water shift reaction, (ii) autothermal reforming of bio-oils produced by pyrolysis, (iii) aqueous phase reforming of sugars and sugar alcohols, and (iv) biological means, enzymes and microorganisms, in dark fermentations (Tanksale et al., 2010). Methane is produced mainly by anaerobic digestion of the biomass ( $\mathrm{Li}$ et al., 2011). The catalytic thermochemical processes do not require a delignification stage of biomass, but this is a necessary step to improve the amount of fermentable carbohydrates if the fuel is to be produced by reforming the gasses produced by anaerobic fermentation of these sugars or by any biological means. Thermochemical and chemical catalyst production of these fuels has been reviewed elsewhere (Kalinci et al., 2009; Tanksale et al., 2010).

\section{Conclusions}

An efficient biorefinery must be capable of using all the components in lignocellulosic wastes resourcefully for the production of fuels in addition to other chemicals and products. Valuable substances contained in these resources must be extracted first. Then, polysaccharides and lignin must be used to produce fuels and other valuable chemicals. Some carbohydrates derived products are: ethanol, carboxylic acids, levulinic acid, glycerol and sorbitol. Lignin, on the other hand, may be used as an energy source through combustion or can be transformed into syngas or bio-oil.

If polysaccharides are to be biologically processed, the lignocelluloses digestibility must be importantly improved. This is achieved by pretreatment, which separate lignin from carbohydrates through chemical or biological means. In some instances, this is achieved by partial delignification or lignin degradation.

Full biological processes are advantageous due to high selectivity and mild reaction conditions, but they are not available yet. Recent studies promote the production of genetically engineered multitask microorganisms able not only to lignocelluloses delignification but also saccharification and fermentation. Additionally, these microorganisms should be marginally inhibited by substrate and product concentration. While this technological dream becomes a scalable economic reality, pretreatments may be carried out by chemical means. In this sense, there is a wide range of possibilities. Advantages and disadvantages of each have been briefly discussed above.

Notable efforts have been conducted to improve ethanol production yields by using lignocellulosic wastes and crops, some of which have been submitted to genetic modifications in the lignin composition. Concurrently, highly desirable integrated processes for non-liquid alternative fuels such as hydrogen are in a very early stage of development. Thus, liquid fuels and products from lignocelluloses can be considered as a bridge between 
the current highly contaminating petroleum age and the future more sophisticated and clean hydrogen combustion age.

\section{References}

Abatzoglou, N., Chornet, E. \& Belkacemil, K. (1992). Phenomenological kinetics of complex systems: The development of a generalized severity parameter and its application to lignocellulosics fractionation. Chemical Engineering Sicence. Vol. 47, No. 5, (April 1992), pp. 1109-1122, ISSN 0009-2509.

Aden, A., Ruth, M., Ibsen, K., Jechura, J., Neeves, K., Sheehan, J. \& Wallace, B. (2002). Lignocellulosic Biomass to Ethanol Process Design and Economics Utilizing Co-Current Dilute Acid Prehydrolysis and Enzymatic Hydrolysis for Corn Stover (1st ed.), National Renewable Energy Lab, Golden, CO.

Agarwal, U. \& Atalla, R. (2010). Vibrational Spectroscopy, In: Lignin and Lignans, Heitner, C., Dimmel, D. \& Schmidt, J., 103-136, CRC Press, ISBN 978-1-57444-486-5, Boca Raton, FL.

Aitken, M.D. \& Irvine, R.L. (1990). Characterization of reactions catalyzed by manganese peroxidase from Phanerochaete chrysosporium. Archives of Biochemistry and Biophysics. Vol. 276, No. 2, (February 1990), pp. 405-14, ISSN 0003-9861.

Alen, R. (2000). Basic Chemistry of Wood Delignification., In: Forest Products Chemistry, Stenius, P., 59-104, Finnish Paper Engineers' Association, ISBN 9-525-216-039, Helsinki, Finland.

Alvarez, J.M., Canessa, P., Mancilla, R.A., Polanco, R., Santibanez, P.A. \& Vicuna, R. (2009). Expression of genes encoding laccase and manganese-dependent peroxidase in the fungus Ceriporiopsis subvermispora is mediated by an ACE1-like copper-fist transcription factor. Fungal Genetics and Biology. Vol. 46, No. 1, (January 2009), pp. 104-11, ISSN 1096-0937.

Ambert-Balay, K., Dougherty, M. \& Tien, M. (2000). Reactivity of manganese peroxidase: site-directed mutagenesis of residues in proximity to the porphyrin ring. Archives of Biochemistry and Biophysics. Vol. 382, No. 1, (October 2000), pp. 89-94, ISSN 00039861.

Arato, C., Pye, E. \& Gjennestad, G. (2005). The lignol approach to biorefining of woody biomass to produce ethanol and chemicals. Applied Biochemistry and Biotechnology. Vol. 123, No. 1-3, (March 2005), pp. 871-882, ISSN 0273-2289.

Arora, D.S. \& Sharma, R.K. (2010). Ligninolytic Fungal Laccases and Their Biotechnological Applications. Applied Biochemistry and Biotechnology. Vol. 160, No. 6, (March 2010), pp. 1760-1788, ISSN 0273-2289.

Bansal, P., Hall, M., Realff, M.J., Lee, J.H. \& Bommarius, A.S. (2009). Modeling cellulase kinetics on lignocellulosic substrates. Biotechnology Advances. Vol. 27, No. 6, (November 2009), pp. 833-848, ISSN 0734-9750.

Betini, J.H., Michelin, M., Peixoto-Nogueira, S.C., Jorge, J.A., Terenzi, H.F. \& Polizeli, M.L. (2009). Xylanases from Aspergillus niger, Aspergillus niveus and Aspergillus ochraceus produced under solid-state fermentation and their application in cellulose pulp bleaching. Bioprocess and Biosystems Engineering. Vol. 32, No. 6, (October 2009), pp. 819-24, ISSN 1615-7605.

Bezalel, L., Shoham, Y. \& Rosenberg, E. (1993). Characterization and delignification activity of a thermostable a-L-arabinofuranosidase from Bacillus stearothermophilus. 
Applied Microbiology and Biotechnology. Vol. 40, No. 1, (January 1993), pp. 57-62, ISSN 0175-7598.

Boerjan, W., Ralph, J. \& Baucher, M. (2003). Lignin Biosynthesis. Annual Review of Plant Biology. Vol. 54, No. 1, (June 2003), pp. 519-46, ISSN 1543-5008.

Bonn, G., Binder, H., Leonhard, H. \& Bobleter, O. (1985). The alkaline degradation of cellobiose to glucose and fructose. Monatshefte für Chemie / Chemical Monthly. Vol. 116, No. 8, pp. 961-971, 0026-9247.

Börjesson, P. \& Tufvesson, L.M. (2011). Agricultural crop-based biofuels - resource efficiency and environmental performance including direct land use changes. Journal of Cleaner Production. Vol. 19, No. 108-120, (January 2011), ISSN 0959-6526.

Bourbonnais, R., Paice, M.G., Freiermuth, B., Bodie, E. \& Borneman, S. (1997). Reactivities of various mediators and laccases with kraft pulp and lignin model compounds. Applied and Environmental Microbiology. Vol. 63, No. 12, (December 1997), pp. 462732, ISSN 0099-2240.

Bringezu, S., Ramesohl, S., Arnold, K., Fischedick, M., von Geibler, J., Liedtkeand, C. \& Schütz, H. (2007). Towards a sustainable biomass strategy. What we know and what we should know. Wuppertal Institute for Climate, Environment and Energy. Vol. 163, (June 2007), ISSN 0949-5266.

Brito, J.O., Silva, F.G., Leão, M.M. \& Almeida, G. (2008). Chemical composition changes in eucalyptus and pinus woods submitted to heat treatment. Bioresource Technology. Vol. 99, No. 18, (December 2008), pp. 8545-8548, ISSN 0960-8524.

Brown, J.A., Alic, M. \& Gold, M.H. (1991). Manganese peroxidase gene transcription in Phanerochaete chrysosporium: activation by manganese. Journal of Bacteriology. Vol. 173, No. 13, (July 1991), pp. 4101-6, ISSN 0021-9193.

Bruinenberg, P.M., de Bot, P.H.M., van Dijken, J.P. \& Scheffers, W.A. (1983). The role of redox balances in the anaerobic fermentation of xylose by yeasts. European Journal of Applied Microbiology and Biotechnology. Vol. 18, No. 5, (September 1983), pp. 287-292, ISSN 0175-7598.

Cardona, C.A., Quintero, J.A. \& Paz, I.C. (2010). Production of bioethanol from sugarcane bagasse: Status and perspectives. Bioresource Technology. Vol. 101, No. 13, (July 2010), pp. 4754-4766, ISSN 0960-8524.

Carrasco, C., Baudel, H.M., Sendelius, J., Modig, T., Roslander, C., Galbe, M., HahnHägerdal, B., Zacchi, G. \& Lidén, G. (2010). SO2-catalyzed steam pretreatment and fermentation of enzymatically hydrolyzed sugarcane bagasse. Enzyme and Microbial Technology. Vol. 46, No. 2, (February 2010), pp. 64-73, ISSN 0141-0229.

Cassman, K.G. \& Liska, A.J. (2007). Food and fuel for all: Realistic or foolish? Biofuels, Bioproducts, and Biorefining. Vol. 1, No. 1, (September 2007), pp. 18-23, ISSN 19321031.

Catal, T., Liu, H. \& Bermek, H. (2008). Selenium induces manganese-dependent peroxidase production by the white-rot fungus Bjerkandera adusta (Willdenow) P. Karsten. Biological Trace Element Research. Vol. 123, No. 1-3, (June 2008), pp. 211-7, ISSN 01634984.

Chandel, A.K., Kapoor, R.K., Singh, A. \& Kuhad, R.C. (2007). Detoxification of sugarcane bagasse hydrolysate improves ethanol production by Candida shehatae NCIM 3501. Bioresource Technology. Vol. 98, No. 10, (July 2007), pp. 1947-1950, ISSN 09608524 . 
Chang, V., Burr, B. \& Holtzapple, M. (1997). Lime pretreatment of switchgrass. Applied Biochemistry and Biotechnology. Vol. 63-65, No. 1, (March 1997), pp. 3-19, ISSN 02732289.

Chang, V. \& Holtzapple, M. (2000). Fundamental factors affecting biomass enzymatic reactivity. Applied Biochemistry and Biotechnology. Vol. 84-86, No. 1, (March 2000), pp. 5-37, ISSN 0273-2289.

Chen, R., Lee, Y. \& Torget, B. (1996). Kinetic and modeling investigation on two-stage reverse-flow reactor as applied to dilute-acid pretreatment of agricultural residues. Applied Biochemistry and Biotechnology, No. 57/58, (March 1996), pp. 133-146, ISSN 0273-2289.

Chen, S., Mowery, R., Castleberry, V., Walsum, P. \& Chamvliss, K. (2006). Highperformance liquid chromatography method for simultaneous determination of aliphatic acid, aromatic acid and neutral degradation products in biomass pretreatment hydrolysates. Journal of Chromatography, No. 1004, (February 2006), pp. 54-61, ISSN 0021-9673.

Chen, Y. (2010). Development and application of co-culture for ethanol production by cofermentation of glucose and xylose: a systematic review. Journal of Industrial Microbiology and Biotechnology. Vol. 38, No. 5, (May 2010), pp. 581-597, ISSN 13675435.

Chiang, C. \& Knight, S.G. (1960). The metabolism of D-xylose by moulds. Nature. Vol. 188, No. 79-81, (October 1960), ISSN 0028-0836.

Cho, D.H., Shin, S.-J., Bae, Y., Park, C. \& Kim, Y.H. (2011). Ethanol production from acid hydrolysates based on the construction and demolition wood waste using Pichia stipitis. Bioresource Technology. Vol. 102, No. 6, (March 2011), pp. 4439-4443, ISSN 0960-8524.

Chum, H., Johnson, D. \& Black, S. (1990). Organosolv pretreatment for enzymic hydrolysis of poplars. 2. Catalyst effects and the combined severity parameter. Industrial and Engineering Chemistry Research. Vol. 29, No. 29, (February 1990), pp. 156-162, ISSN 0888-5885.

Clough, R.C., Pappu, K., Thompson, K., Beifuss, K., Lane, J., Delaney, D.E., Harkey, R., Drees, C., Howard, J.A. \& Hood, E.E. (2006). Manganese peroxidase from the white-rot fungus Phanerochaete chrysosporium is enzymatically active and accumulates to high levels in transgenic maize seed. Plant Biotechnology Journal. Vol. 4, No. 1, (January 2006), pp. 53-62, ISSN 1467-7652.

Costa, S.M., Gonçalves, A.R. \& Esposito, E. (2002). Action of white-rot fungus Panus tigrinus on sugarcane bagasse: Evaluation of selectivity. Applied Biochemistry and Biotechnology - Part A Enzyme Engineering and Biotechnology. Vol. 98-100, (March 2002), pp. 357-364, ISSN 0273-2289.

Costa, S.M., Gonçalves, A.R. \& Esposito, E. (2005). Ceriporiopsis subvermispora used in delignification of sugarcane bagasse prior to soda/anthraquinone pulping. Applied Biochemistry and Biotechnology - Part A Enzyme Engineering and Biotechnology. Vol. 122, No. 1-3, (March 2005), pp. 695-706, ISSN 0273-2289.

Crawford, D.L., Doyle, J.D., Wang, Z., Hendricks, C.W., Bentjen, S.A., Bolton, H., Jr., Fredrickson, J.K. \& Bleakley, B.H. (1993). Effects of a lignin peroxidase-expressing recombinant, Streptomyces lividans TK23.1, on biogeochemical cycling and the 
numbers and activities of microorganisms in soil. Applied and Environmental Microbiology. Vol. 59, No. 2, (February 1993), pp. 508-18, ISSN 0099-2240.

Daniel, G., Nilsson, T. \& Pettersson, B. (1989). Intra- and Extracellular Localization of Lignin Peroxidase during the Degradation of Solid Wood and Wood Fragments by Phanerochaete chrysosporium by Using Transmission Electron Microscopy and Immuno-Gold Labeling. Applied and Environmental Microbiology. Vol. 55, No. 4, (April 1989), pp. 871-81, ISSN 0099-2240.

de Groot, B., Van Dam, J.E.G., van der Zwan, R.P. \& Riet, K.v. (1994). Simplified Kinetic Modelling of Alkaline Delignification of Hemp Woody Core. Holzforschung. Vol. 48, No. 3, (March 1994), pp. 207-214, ISSN 0018-3830.

Dekker, R.F., Barbosa, A.M., Giese, E.C., Godoy, S.D. \& Covizzi, L.G. (2007). Influence of nutrients on enhancing laccase production by Botryosphaeria rhodina MAMB-05. International Microbiology. Vol. 10, No. 3, (September 2007), pp. 177-85, ISSN 11396709.

Diamantidis, G., Effosse, A., Potier, P. \& Bally, R. (2000). Purification and characterization of the first bacterial laccase in the rhizospheric bacterium Azospirillum lipoferum. Soil Biology and Biochemistry. Vol. 32, No. 7, (July 2000), pp. 919-927 ISSN 0038-0717.

Dias, A.A., Freitas, G.S., Marques, G.S., Sampaio, A., Fraga, I.S., Rodrigues, M.A., Evtuguin, D.V. \& Bezerra, R.M. (2010). Enzymatic saccharification of biologically pre-treated wheat straw with white-rot fungi. Bioresourse Thecnology. Vol. 101, No. 15, (August 2010), pp. 6045-50, ISSN 1873-2976.

Dimmel, D. (2010). Overview, In: Lignin and Lignans, Heitner, C., Dimmel, D. \& Schmidt, J., 1-10, CRC Press, ISBN 978-1-57444-486-5, Boca Raton, FL.

Dolan, G.A. (2010). Methanol Production and Utilization (1st ed.), Blackwell Publishing Ltd., ISBN 9780-470-750-025, Hoboken, NJ.

Dorado, J., Almendros, G., Camarero, S., Martínez, A.T., Vares, T. \& Hatakka, A. (1999). Transformation of wheat straw in the course of solid-state fermentation by four ligninolytic basidiomycetes. Enzyme and Microbial Technology. Vol. 25, No. 7, (October 1999), pp. 605-612, ISSN 0141-0229.

Duf, S. \& Murray, W. (1996). Bioconversion of forest products industry waste cellulosics to fuel ethanol: A review. Bioresource Technology. Vol. 55, No. 1, (n.d.), pp. 1-33, ISSN 0960-8524

Dwivedi, P., Vivekanand, V., Pareek, N., Sharma, A. \& Singh, R.P. (2010). Bleach enhancement of mixed wood pulp by xylanase-laccase concoction derived through co-culture strategy. Applied Biochemistry and Biotechnology. Vol. 160, No. 1, (January 2010), pp. 255-268, ISSN 0273-2289.

Dwivedi, U.N., Singha, P., Pandeya, V.P. \& Kumara, A. (2011). Structure-function relationship among bacterial, fungal and plant laccases. Journal of Molecular Catalysis B: Enzymatic. Vol. 68, No. 2, (Febrary 2011), pp. 117-128, ISSN 1381-1177.

Eggeman, T. \& Elander, R.T. (2005). Process and economic analysis of pretreatment technologies. Bioresource Technology. Vol. 96, No. 18, (December 2005), pp. 20192025, ISSN 0960-8524.

Eliasson, A., Christensson, C., Wahlbom, C.F. \& Hahn-Hagerdal, B. (2000). Anaerobic Xylose Fermentation by Recombinant Saccharomyces cerevisiae Carrying XYL1, XYL2, and XKS1 in Mineral Medium Chemostat Cultures. Applied and Environmental Microbiology. Vol. 66, No. 8, (August 1, 2000), pp. 3381-3386. 
Eliasson, A., Hofmeyr, J.-H.S., Pedler, S. \& Hahn-Hägerdal, B. (2001). The xylose reductase/xylitol dehydrogenase/xylulokinase ratio affects product formation in recombinant xylose-utilising Saccharomyces cerevisiae. Enzyme and Microbial Technology. Vol. 29, No. 4-5, (September 2001), pp. 288-297, ISSN 0141-0229.

Elisashvili, V. \& Kachlishvili, E. (2009). Physiological regulation of laccase and manganese peroxidase production by white-rot Basidiomycetes. Journal of Biotechnology. Vol. 144, No. 1, (October 2009), pp. 37-42, ISSN 1873-4863.

Esteghlalian, A., Hashimoto, A., Fenske, J. \& Penner, M. (1997). Modeling and optimization of the dilute sulfuric-acid pretreatment of corn stover, poplar and switchgrass. Bioresource Technology. Vol. 59, No. 2-3, (February 1997), pp. 129-136, ISSN 09608524 .

FAO. (2008). Food and Agricultural commodities production. http://faostat.fao.org/site/339/default.aspx.

Ferris, J. \& Joshi, S. (2010). Prospects for Ethanol and Biodiesel, 2008 to 2017 and Impacts on Agriculture and Food, In: Handbook of Bioenergy Economics and Policy, Khanna, M., Scheffran, J. \& Zilberman, D., 91-111, Springer, ISBN 978-1-4419-0369-3, New York.

Fissore, A., Carrasco, L., Reyes, P., Rodríguez, J., Freer, J. \& Mendonça, R.T. (2010). Evaluation of a combined brown rot decay-chemical delignification process as a pretreatment for bioethanol production from Pinus radiata wood chips. Journal of Industrial Microbiology and Biotechnology. Vol. 37, No. 9, (May 2010), pp. 893-900, ISSN 1367-5435.

Frederick Jr, W.J., Lien, S.J., Courchene, C.E., DeMartini, N.A., Ragauskas, A.J. \& Iisa, K. (2008). Co-production of ethanol and cellulose fiber from Southern Pine: A technical and economic assessment. Biomass and Bioenergy. Vol. 32, No. 12, (December 2008), pp. 1293-1302, ISSN 0961-9534.

Gaitan, I.J., Medina, S.C., Gonzalez, J.C., Rodriguez, A., Espejo, A.J., Osma, J.F., Sarria, V., Almeciga-Diaz, C.J. \& Sanchez, O.F. (2011). Evaluation of toxicity and degradation of a chlorophenol mixture by the laccase produced by Trametes pubescens. Bioresource Technology. Vol. 102, No. 3, (February 2011), pp. 3632-5, ISSN 1873-2976.

Galbe, M. \& Zacchi, G. (2002). A review of the production of ethanol from softwood. Applied Microbiology and Biotechnology. Vol. 59, No. 6, (September 2002), pp. 618-628, ISSN 0175-7598.

Galhaup, C., Goller, S., Peterbauer, C.K., Strauss, J. \& Haltrich, D. (2002). Characterization of the major laccase isoenzyme from Trametes pubescens and regulation of its synthesis by metal ions. Microbiology. Vol. 148, No. Pt 7, (July 2002), pp. 2159-69, ISSN 1350-0872.

Garlock, R.J., Balan, V., Dale, B.E., Ramesh Pallapolu, V., Lee, Y.Y., Kim, Y., Mosier, N.S., Ladisch, M.R., Holtzapple, M.T., Falls, M., Sierra, R., Shi, J., Ebrik, M.A., Redmond, T., Yang, B., Wyman, C.E., Donohoe, B.S., Vinzant, T.B., Elander, R.T., Hames, B., Thomas, S. \& Warner, R.E. (2011). Comparative material balances around leading pretreatment technologies for the conversion of switchgrass to soluble sugars. Bioresource Technology. Vol. In Press, (n.d.), ISSN 0960-8524.

Ghodake, G.S., Kalme, S.D., Jadhav, J.P. \& Govindwar, S.P. (2009). Purification and partial characterization of lignin peroxidase from Acinetobacter calcoaceticus NCIM 2890 and its application in decolorization of textile dyes. Applied Biochemistry and Biotechnology. Vol. 152, No. 1, (January 2009), pp. 6-14, ISSN 1559-0291. 
Gierer, J. \& Stockholm, S. (1985). Chemistry of delignification. Part 1: General concept and reactions during pulping. Wood Science and Technology. Vol. 19, (n.d.), pp. 289-312, ISSN 0043-7719.

Glasser, W.G. \& Sarkanen, S. (1989). Lignin (American Chemical Society, ISBN 0-8412-1631-2, Washington, DC.

Goldemberg, J. (2006). The promise of clean energy. Energy Policy. Vol. 34, (Octuber 2006), pp. 2185-2190, ISSN 0301-4215.

Gonçalves, A.R., Esposito, E. \& Benar, P. (1998). Evaluation of Panus tigrinus in the delignification of sugarcane bagasse by FTIR-PCA and pulp properties. Journal of Biotechnology. Vol. 66, No. 2-3, (December 1998), pp. 177-185, ISSN 0168-1656.

Grohmann, K., Torget, R. \& Himmel, M. (1985). Optimization of dilute-acid pretreatment of biomass. Biotechnology and Bioengineering Symposium. Vol. 15, (n.d.), pp. 59-80, ISSN 0572-6565.

Gu, L., Lajoie, C. \& Kelly, C. (2003). Expression of a Phanerochaete chrysosporium manganese peroxidase gene in the yeast Pichia pastoris. Biotechnology Progress. Vol. 19, No. 5, (September 2003), pp. 1403-9, ISSN 8756-7938.

Guay, D.F. (2000). Mechanisms of Oxidative Degradation of Carbohydrates During Oxygen delignification. I. Reaction of Photochemically generated Hydroxyl Radical with Methyl $\beta$-D-Glucoside. Journal of Wood Chemistry and Technology. Vol. 20, No. 4, (n.d.), pp. 375-394, ISSN 0277-3813.

Guo, G.-L., Hsu, D.-C., Chen, W.-H., Chen, W.-H. \& Hwang, W.-S. (2009). Characterization of enzymatic saccharification for acid-pretreated lignocellulosic materials with different lignin composition. Enzyme and Microbial Technology. Vol. 45, No. 2, (August 2009), pp. 80-87, ISSN 0141-0229.

Guo, M., Lu, F., Du, L., Pu, J. \& Bai, D. (2006). Optimization of the expression of a laccase gene from Trametes versicolor in Pichia methanolica. Applied Microbiology and Biotechnology. Vol. 71, No. 6, (August 2006), pp. 848-52, ISSN 0175-7598.

Gupta, R., Mehta, G., Khasa, Y.P. \& Kuhad, R.C. (2010). Fungal delignification of lignocellulosic biomass improves the saccharification of cellulosics. Biodegradation. Vol. In press, (August 2010), ISSN 0923-9820.

Haddadin, M.S., Al-Natour, R., Al-Qsous, S. \& Robinson, R.K. (2002). Bio-degradation of lignin in olive pomace by freshly-isolated species of Basidiomycete. Bioresource Technology. Vol. 82, No. 2, (April 2002), pp. 131-137, ISSN 0960-8524.

Hammel, K.E. \& Cullen, D. (2008). Role of fungal peroxidases in biological ligninolysis. Current Opinion in Plant Biology. Vol. 11, No. 3, (June 2008), pp. 349-55, ISSN 13695266.

Harmsen, P., Huijgen, W., Bermúdez-López, L. \& Bakker, R. (2010). Literature Review of Physical and Chemical Pretreatment Processes for Lignocellulosic Biomass (1st ed.), ISBN 9789-085-857-570, Netherlands.

Hatakeyama, H. \& Hatakeyama, T. (2010a). Lignin Structure, Properties, and Applications, In: Biopolymers, Abe, A., Dusek, K. \& Kobayashi, S., 1-63, Springer, ISBN 9783-64213629-0, Berlin.

Hatakeyama, H. \& Hatakeyama, T. (2010b). Thermal Properties of Isolated and in situ Lignin, In: Lignin and Lignans, Heitner, C., Dimmel, D. \& Schmidt, J., 301-319, CRC Press, ISBN 978-1-57444-486-5, Boca Raton, FL. 
Hatakeyama, T. \& Hatakeyama, H. (2005). Lignin, In: Thermal Properties of Green Polymers and Biocomposites, Hatakeyama, T. \& Hatakeyama, H., 171-215, Springer, ISBN 1-40202354-5, Netherlands.

Hodgson, E.M., Lister, S.J., Bridgwater, A.V., Clifton-Brown, J. \& Donnison, I.S. (2010). Genotypic and environmentally derived variation in the cell wall composition of Miscanthus in relation to its use as a biomass feedstock. Biomass and Bioenergy. Vol. 34, No. 5, (May 2010), pp. 652-660, ISSN 0961-9534.

Holtzapple, M. \& Humphrey, A. (1984). The effect of organosolv pretreatment on the enzymic hydrolysis of poplar. Biotechnology and Bioengineering. Vol. 26, No. 7, (July 1984), pp. 670-676, ISSN 0006-3592.

Holtzapple, M., Jun, J., Ganesh, A., Srinivas, P. \& Dale, B. (1991). The Ammonia Freeze Explosion (AFEX) Process: A Practical Lignocellulose Pretreatment. Applied Biochemistry and Biotechnology. Vol. 28-29, No. 1, (March 1991), pp. 59-74, ISSN 02732289.

Hong, Y.Z., Zhou, H.M., Tu, X.M., Li, J.F. \& Xiao, Y.Z. (2007). Cloning of a laccase gene from a novel basidiomycete Trametes sp. 420 and its heterologous expression in Pichia pastoris. Current Microbiology. Vol. 54, No. 4, (April 2007), pp. 260-5, ISSN 03438651.

Jiang, F., Kongsaeree, P., Schilke, K., Lajoie, C. \& Kelly, C. (2008). Effects of pH and temperature on recombinant manganese peroxidase production and stability. Applied Microbiology and Biotechnology. Vol. 146, No. 1-3, (March 2008), pp. 15-27, ISSN 1559-0291.

Jin, S. \& Chen, H. (2007). Near-infrared analysis of the chemical composition of rice straw. Industrial Crops and Products. Vol. 26, No. 2, (August 2007), pp. 207-211, ISSN 09266690.

Johanson, A., Aaltonen, O. \& Ylinen, P. (1987). Organosolv pulping - method and pulp properties. Biomass. Vol. 13, No. 1, (n.d.), pp. 45-65, ISSN 0144-4565.

Johansson, T. \& Nyman, P.O. (1996). A cluster of genes encoding major isozymes of lignin peroxidase and manganese peroxidase from the white-rot fungus Trametes versicolor. Gene. Vol. 170, No. 1, (April 1996), pp. 31-8, ISSN 0378-1119.

Johjima, T., Itoh, N., Kabuto, M., Tokimura, F., Nakagawa, T., Wariishi, H. \& Tanaka, H. (1999). Direct interaction of lignin and lignin peroxidase from Phanerochaete chrysosporium. Proceedings of the National Academy of Sciences of the United States of America. Vol. 96, No. 5, (March 1999), pp. 1989-94, ISSN 0027-8424.

Kalinci, Y., Hepbasli, A. \& Dincer, I. (2009). Biomass-based hydrogen production: A review and analysis. International Journal of Hydrogen Energy. Vol. 34, No. 21, (November 2009), pp. 8799-8817, ISSN 0360-3199.

Kambam, P.K.R. \& Henson, M.A. (2010). Engineering bacterial processes for cellulosic ethanol production. Biofuels. Vol. 1, No. 5, (September 2010), pp. 729-743, ISSN 1759-7269.

Kanayama, N., Tohru, S. \& Keiichi, K. (2002). Purification and characterization of an alkaline manganese peroxidase from Aspergillus terreus LD-1. Journal of Bioscience and Bioengineering. Vol. 93, No. 4, (April 2002), pp. 405-10, ISSN 1389-1723.

Kannan, K., Oblisami, G. \& Loganathan, B.G. (1990). Enzymology of ligno-cellulose degradation by Pleurotus sajor-caju during growth on paper-mill sludge. Biological Wastes. Vol. 33, No. 1, (January 1990), pp. 1-8, ISSN 0269-7483. 
Kaparaju, P., Serrano, M., Thomsen, A.B., Kongjan, P. \& Angelidaki, I. (2009). Bioethanol, biohydrogen and biogas production from wheat straw in a biorefinery concept. Bioresource Technology. Vol. 100, No. 9, (May 2009), pp. 2562-8, ISSN 1873-2976.

Kaur, A., Mahajan, R., Singh, A., Garg, G. \& Sharma, J. (2010). Application of cellulase-free xylano-pectinolytic enzymes from the same bacterial isolate in biobleaching of kraft pulp. Bioresource Technology. Vol. 101, No. 23, (July 2010), pp. 9150-9155, ISSN 18732976.

Keegstra, K. (2010). Plant cell walls. Plant Physiology. Vol. 154, No. 2, (October 2010), pp. $483-$ 6, ISSN 1532-2548.

Khalil, H.P.S.A., Alwani, M.S. \& Omar, A.K.M. (2006). Chemical composition, anatomy, lignin distribution, and cell wall structure of Malaysian plant waste fibers. BioResources. Vol. 1 No. 2, (November 2006), pp. 220-232., ISSN 1930-2126.

Kim, S. \& Holtzapple, M.T. (2005). Lime pretreatment and enzymatic hydrolysis of corn stover. Bioresource Technology. Vol. 96, No. 18, (December 2005), pp. 1994-2006, ISSN 0960-8524.

Kim, S. \& Holtzapple, M.T. (2006). Delignification kinetics of corn stover in lime pretreatment. Bioresource Technology. Vol. 97, No. 5, (March 2006), pp. 778-785, ISSN 0960-8524.

Kim, T.H., Kim, J.S., Sunwoo, C. \& Lee, Y.Y. (2003). Pretreatment of corn stover by aqueous ammonia. Bioresource Technology. Vol. 90, No. 1, (October 2003), pp. 39-47, ISSN 0960-8524.

Klinke, H.B., Ahring, B.K., Schmidt, A.S. \& Thomsen, A.B. (2002). Characterization of degradation products form alkaline wet oxidation of wheat straw. Bioresource Technology. Vol. 82, (March 2002), pp. 15-26, ISSN 0960-8524.

Kocheva, L., Karmanov, A., Mironov, M., Belyi, V., Belyaev, V. \& Monakov, Y. (2008). Straw lignins: Hydrodynamic and conformational properties of the macromolecules. Russian Journal of Applied Chemistry. Vol. 81, No. 11, (November 2008), pp. 20332039, ISSN 1070-4272.

Kopelman, R. (1988). Fractal Reaction Kinetics. Science. Vol. 241, No. 4873, (September 1988), pp. 1620-1626, ISSN 0036-8075.

Kosugi, A., Kondo, A., Ueda, M., Murata, Y., Vaithanomsat, P., Thanapase, W., Arai, T. \& Mori, Y. (2009). Production of ethanol from cassava pulp via fermentation with a surface-engineered yeast strain displaying glucoamylase. Renewable Energy. Vol. 34, No. 5, (May 2009), pp. 1354-1358, ISSN 0960-1481.

Kumar, P., Barrett, D., Delwiche, M. \& Stroeve, P. (2009). Methods for pretreatment of lignocellulosic biomass for efficient hydrolysis and biofuel production. Industrial and Engineering Chemistry Research. Vol. 48, No. 8, (March 2009), pp. 3713-3729, ISSN 0888-5885.

Kumar, R. \& Wyman, C. (2009). Does change in accesibility with conversion depend on both the substrate and the pretreatment technology? Bioresource Technology, No. 100, (September 2009), pp. 4193-4202, ISSN 0960-8524.

Lee, J. (1997). Biological conversion of lignocellulosic biomass to ethanol. Journal of Biotechnology. Vol. 56, No. 1, (July 1997), pp. 1-24, ISSN 0168-1656.

Lee, J. \& Jeffries, T. (2011). Efficiencies of acid catalyst in the hydrolysis of lignocellulosic biomass over a range of combined severity factors. Bioresource Technology. Vol. In press, (n.d.), ISSN 0960-8524. 
Lee, Y., Zhangwen, W. \& Torget, R. (2000). Modeling of countercurrent shringking-bed reactor in dilute-acid total-hydrolysis of lignocellulosic biomass. Bioresource Technology. Vol. 71, No. 1, (January 2000), pp. 29-39, ISSN 0960-8524.

Li, B.-Z., Balan, V., Yuan, Y.-J. \& Dale, B.E. (2010). Process optimization to convert forage and sweet sorghum bagasse to ethanol based on ammonia fiber expansion (AFEX) pretreatment. Bioresource Technology. Vol. 101, No. 4, (February 2010), pp. 1285-1292, ISSN 0960-8524.

Li, J., Gunnar, H. \& Góran, G. (2007). Lignin depolymerization/repolymerization and its critical role for deligniWcation of aspen wood by steam explosion. Bioresource Technology. Vol. 98, (n.d.), pp. 3061-3068, ISSN 0960-8524.

Li, J., Henriksoon, G. \& Gellerstedt, G. (2005). Carbohydrate reactions during hightemperature steam treatment of aspen wood. Applied Biochemistry and Biotechnology. Vol. 125, No. 3, (June 2005), pp. 175-188, ISSN 0273-2289.

Li, X., Kondo, R. \& Sakai, K. (2002). Biodegradation of sugarcane bagasse with marine fungus Phlebia sp. MG-60. Journal of Wood Science. Vol. 48, No. 2, (April 2002), pp. 159-162, ISSN 1435-0211.

Li, Y., Park, S.Y. \& Zhu, J. (2011). Solid-state anaerobic digestion for methane production from organic waste. Renewable and Sustainable Energy Reviews. Vol. 15, No. 1, (January 2011), pp. 821-826, ISSN 1364-0321.

Lu, C., Wang, H., Luo, Y. \& Guo, L. (2010). An efficient system for pre-delignification of gramineous biofuel feedstock in vitro: Application of a laccase from Pycnoporus sanguineus H275. Process Biochemistry. Vol. 45, No. 7, (July 2010), pp. 1141-1147, ISSN 1359-5113.

Martinez, A.T., Ruiz-Duenas, F.J., Martinez, M.J., Del Rio, J.C. \& Gutierrez, A. (2009). Enzymatic delignification of plant cell wall: from nature to mill. Current Opinion in Biotechnology. Vol. 20, No. 3, (June 2009), pp. 348-57, ISSN 1879-0429.

Martinez, A.T., Speranza, M., Ruiz-Duenas, F.J., Ferreira, P., Camarero, S., Guillen, F., Martinez, M.J., Gutierrez, A. \& del Rio, J.C. (2005). Biodegradation of lignocellulosics: microbial, chemical, and enzymatic aspects of the fungal attack of lignin. International Microbiology. Vol. 8, No. 3, (September 2005), pp. 195-204, ISSN 1139-6709.

McMillan, J. Process for pretreating lignocellulosic biomass: a review, In: National Renewable Energy Laboratory, Available from: http:/ / www.osti.gov/energycitations / product.biblio.jsp?osti_id=7171656

Meza, J.C., Sigoillot, J.C., Lomascolo, A., Navarro, D. \& Auria, R. (2006). New process for fungal delignification of sugar-cane bagasse and simultaneous production of laccase in a vapor phase bioreactor. Journal of Agricultural and Food Chemis ry. Vol. 54, No. 11, (May 2006), pp. 3852-8, ISSN 0021-8561.

Mielenz, J.R. (2001). Ethanol production from biomass: technology and commercialization status. Current Opinion in Microbiology. Vol. 4, No. 3, (June 2001), pp. 324-329, ISSN 1369-5274.

Mishra, M. \& Thakur, I.S. (2010). Isolation and characterization of alkalotolerant bacteria and optimization of process parameters for decolorization and detoxification of pulp and paper mill effluent by Taguchi approach. Biodegradation. Vol. 21, No. 6, (April 2010), pp. 967-978, ISSN 0923-9820. 
Morinelly, J., Jensen, J., Browne, M., Co, T. \& Shonnard, D. (2009). Kinetic characterization of xylose monomer and oligomer concentrations during dilute acid pretreatment of lignocellulosic biomass from forests and switchgrass. Industrial and Engineering Chemistry Research. Vol. 48, No. 22, (September 2009), pp. 9877-9884, ISSN 08885885 .

Mosier, N., Wyman, C., Dale, B., Elander, R., Lee, Y.Y., Holtzapple, M. \& Ladisch, M. (2005). Features of promising technologies for pretreatment of lignocellulosic biomass. Bioresource Technology. Vol. 96, No. 6, (April 2005), pp. 673-686, ISSN 0960-8524.

Mussatto, S.I. \& Roberto, I.C. (2004). Alternatives for detoxification of diluted-acid lignocellulosic hydrolyzates for use in fermentative processes: a review. Bioresource Technology. Vol. 93, No. 1, (May 2004), pp. 1-10, ISSN 0960-8524.

Naik, S.N., Goud, V.V., Rout, P.K. \& Dalai, A.K. (2010). Production of first and second generation biofuels: A comprehensive review. Renewable and Sustainable Energy Reviews. Vol. 14, (February 2010), pp. 578-597, ISSN 1364-032.

Nanguneri, D. \& Hester, R. (1990). Acid/sugar separation using ion exclusion resins: A process analysis and a design. Separation Science and Technology. Vol. 25, No. 13-15, (n.d.), pp. 1829-1842, ISSN 1520-5754.

Nichols, N.N., Dien, B.S. \& Cotta, M.A. (2010). Fermentation of bioenergy crops into ethanol using biological abatement for removal of inhibitors. Bioresource Technology. Vol. 101, No. 19, (October 2010), pp. 7545-7550, ISSN 0960-8524.

Nie, G., Reading, N.S. \& Aust, S.D. (1998). Expression of the lignin peroxidase H2 gene from Phanerochaete chrysosporium in Escherichia coli. Biochemical and Biophysical Research Communications. Vol. 249, No. 1, (August 1998), pp. 146-50, ISSN 0006291X.

Osono, T. \& Takeda, H. (2006). Fungal decomposition of Abies needle and Betula leaf litter. Mycologia. Vol. 98, No. 2, (March 2006), pp. 172-179, ISSN 0027-5514.

Palmqvist, E. \& Hahn-Hägerdal, B. (2000). Fermentation of lignocellulosic hydrolysates. I: inhibition and detoxification. Bioresource Technology. Vol. 74, No. 1, (August 2000), pp. 17-24, ISSN 0960-8524.

Pan, X., Gilkes, N. \& Saddler, J. (2006). Effect of acetyl groups on enzymatic hydrolysis of cellulosic substrates. Holzforschung. Vol. 60, No. 4, (n.d.), pp. 398-401, ISSN 00183830.

Pandey, P. \& Pandey, A.K. (2002). Production of cellulase-free thermostable xylanases by an isolated strain of Aspergillus niger PPI, utilizing various lignocellulosic wastes. World Journal of Microbiology and Biotechnology. Vol. 18, No. 3, (April 2002), pp. 281283, ISSN 0959-3993.

Pellinen, J., Abuhasan, J., Joyce, T.W. \& Chang, H.M. (1989). Biological delignification of pulp by Phanerochaete chrysosporium. Journal of Biotechnology. Vol. 10, No. 2, pp. 161-170, ISSN 01681656.

Perez, J., Munoz-Dorado, J., de la Rubia, T. \& Martinez, J. (2002). Biodegradation and biological treatments of cellulose, hemicellulose and lignin: an overview. International Microbiology. Vol. 5, No. 2, (June 2002), pp. 53-63, ISSN 1139-6709.

Piarpuzán, D., Quintero, J.A. \& Cardona, C.A. (2011). Empty fruit bunches from oil palm as a potential raw material for fuel ethanol production. Biomass and Bioenergy. Vol. 35, No. 3, (March 2011), pp. 1130-1137, ISSN 0961-9534. 
Pingali, S., Urban, V., Heller, W., McGaughey, J., O’Neill, H., Foston, M., Myles, D., Ragauskas, A. \& Evans, B. (2010). Breakdown of Cell Wall Nanostructure in Dilute Acid Pretreated Biomass. Biomacromolecules. Vol. 11, No. 9, (August 2010), pp. 23292335, ISSN 1525-7797.

Piontek, K., Smith, A.T. \& Blodig, W. (2001). Lignin peroxidase structure and function. Biochemical Society Transactions. Vol. 29, No. Pt 2, (May 2001), pp. 111-6, ISSN 03005127.

PRB. 2010 World Population Data Sheet, In: Population Reference Burea, Available from: http://www.prb.org/pdf10/10wpds_eng.pdf

Punelli, F., Reverberi, M., Porretta, D., Nogarotto, S., Fabbri, A.A., Fanelli, C. \& Urbanelli, S. (2009). Molecular characterization and enzymatic activity of laccases in two Pleurotus spp. with different pathogenic behaviour. Mycological Research. Vol. 113, No. Pt 3, (March 2009), pp. 381-7, ISSN 0953-7562.

Ragauskas, A.J., Williams, C.K., Davison, B.H., Britovsek, G., Cairney, J., Eckert, C.A., Frederick, W.J., Jr., Hallett, J.P., Leak, D.J., Liotta, C.L., Mielenz, J.R., Murphy, R., Templer, R. \& Tschaplinski, T. (2006). The path forward for biofuels and biomaterials. Science. Vol. 311, No. 5760, (January 2006), pp. 484-9, ISSN 1095-9203.

Ralph, J. \& Landucci, L. (2010). NMR of Lignins, In: Lignin and Lignans, Heitner, C., Dimmel, D. \& Schmidt, J., 137-243, CRC Press, ISBN 1-57444-486-5, Boca Raton, FL.

Ranieri, D., Colao, M.C., Ruzzi, M., Romagnoli, G. \& Bianchi, M.M. (2009). Optimization of recombinant fungal laccase production with strains of the yeast Kluyveromyces lactis from the pyruvate decarboxylase promoter. FEMS Yeast Research. Vol. 9, No. 6, (September 2009), pp. 892-902, ISSN 1567-1364.

Reddy, N. \& Yang, Y. (2005). Biofibers from agricultural byproducts for industrial applications. Trends in Biotechnology. Vol. 23, No. 1, (January 2005), pp. 22-7, ISSN 0167-7799.

Riva, S. (2006). Laccases: blue enzymes for green chemistry. Trends in Biotechnology. Vol. 24, No. 5, (May 2006), pp. 219-26, ISSN 0167-7799.

Rodriguez, E., Ruiz-Duenas, F.J., Kooistra, R., Ram, A., Martinez, A.T. \& Martinez, M.J. (2008). Isolation of two laccase genes from the white-rot fungus Pleurotus eryngii and heterologous expression of the pel3 encoded protein. Journal of Biotechnology. Vol. 134, No. 1-2, (March 2008), pp. 9-19, ISSN 0168-1656.

Ruiz, E., Cara, C., Ballesteros, M., Manzanares, P., Ballesteros, I. \& Castro, E. (2006). Ethanol Production From Pretreated Olive Tree Wood and Sunflower Stalks by an SSF Process, In: Twenty-Seventh Symposium on Biotechnology for Fuels and Chemicals, McMillan, J. D., Adney, W. S., Mielenz, J. R. \& Klasson, K. T., 631-643, Humana Press, ISBN 978-1-59745-268-7, New York, NY.

Ryu, K., Kang, J.H., Wang, L. \& Lee, E.K. (2008). Expression in yeast of secreted lignin peroxidase with improved 2,4-dichlorophenol degradability by DNA shuffling. Journal of Biotechnology. Vol. 135, No. 3, (June 2008), pp. 241-6, ISSN 0168-1656.

Saloheimo, M., Barajas, V., Niku-Paavola, M.L. \& Knowles, J.K. (1989). A lignin peroxidaseencoding cDNA from the white-rot fungus Phlebia radiata: characterization and expression in Trichoderma reesei. Gene. Vol. 85, No. 2, (December 1989), pp. 343-51, ISSN 0378-1119.

Salony, Garg, N., Baranwal, R., Chhabra, M., Mishra, S., Chaudhuri, T.K. \& Bisaria, V.S. (2008). Laccase of Cyathus bulleri: structural, catalytic characterization and 
expression in Escherichia coli. Biochimica et Biophysica Acta. Vol. 1784, No. 2, (February 2008), pp. 259-68, ISSN 0006-3002.

Sanchez, D. Recausticizing: Principles and practice, In: Vector process equipment Inc., Available from: http://www.tappi.org/content/events/08kros/manuscripts/21.pdf

Sánchez, Ó.J. \& Cardona, C.A. (2008). Trends in biotechnological production of fuel ethanol from different feedstocks. Bioresource Technology. Vol. 99, No. 13, (September 2008), pp. 5270-5295, ISSN 0960-8524.

Sannigrahi, P., Ragauskas, A. \& Miller, S. (2008). Effects of Two-Stage Dilute Acid Pretreatment on the Structure and Composition of Lignin and Cellulose in Loblolly Pine Bioenegy Research. Vol. 1, No. 3-4, (December 2008), pp. 205-214, ISSN 19391234.

Sarkanen, S., Razal, R.A., Piccariello, T., Yamamoto, E. \& Lewis, N.G. (1991). Lignin peroxidase: toward a clarification of its role in vivo. Journal of Biological Chemistry. Vol. 266, No. 6, (February 1991), pp. 3636-43, ISSN 0021-9258.

Schell, D., Farmer, J., Newman, M. \& McMillan, J. (2003). Dilute-sulfuric acid pretreatment of corn stover in pilot-scale reactor. Applied Biochemistry and Biotechnology. Vol. 105, No. 1, (n.d.), pp. 69-85, ISSN 0273-2289.

Scheller, H.V. \& Ulvskov, P. (2010). Hemicelluloses. Annual Review of Plant Biology. Vol. 61, No. 1, (Junuary 2010), pp. 263-89, ISSN 1545-2123.

Schmidt, J. (2010). Electronic Spectroscopy of Lignins, In: Lignin and Lignans, Heitner, C., Dimmel, D. \& Schmidt, J., 49-102, CRC Press, ISBN 1-57444-486-5, Boca Raton.

Selig, M.J., Viamajala, S., Decker, S.R., Tuker, M.P. \& Himmel, M.E. (2007). Deposition of lignin droplets produced during dilute acid pretreatment of maize stems retards enzymatic hydrolysis of cellulose. Biotechnology Progress. Vol. 23, No. 6, (November 2007), pp. 1333-1339, ISSN 8756-7938.

Shafiee, S. \& Topal, E. (2009). When will fossil fuel reserves be diminished? Energy Policy. Vol. 37, No. 1, (January 2009), pp. 181-189, ISSN 0301-4215.

Shao, Q., Chundawat, S., Krishnan, C., Bals, B., Leonardo, da Costa Sousa, L., Thelen, K., Dale, B. \& Balan, V. (2010). Enzymatic digestibility and ethanol fermentability of AFEX-treated starch-rich lignocellulosics such as corn silage and whole corn plant. Biotechnology for biofuels. Vol. 3, No. 12, (January 2010), ISSN 1754-6834.

Sharma, R.K. \& Arora, D.S. (2010). Changes in biochemical constituents of paddy straw during degradation by white rot fungi and its impact on in vitro digestibility. Journal of Applied Microbiology. Vol. 109, No. 2, (February 2010), pp. 679-686, ISSN 1364-5072.

Sharma, S.K., Kalra, K.L. \& Grewal, H.S. (2002). Enzymatic saccharification of pretreated sunflower stalks. Biomass and Bioenergy. Vol. 23, No. 3, (September 2002), pp. 237243, ISSN 0961-9534.

Shi, J., Sharma-Shivappa, R.R. \& Chinn, M.S. (2009). Microbial pretreatment of cotton stalks by submerged cultivation of Phanerochaete chrysosporium. Bioresource Technology. Vol. 100, No. 19, (October 2009), pp. 4388-95, ISSN 1873-2976.

Sierra, R., García, L. \& Holtzapple, M. (2011a). Selectivity and delignification kinetics for oxidative short-term lime pretreatment of poplar wood. Part I: constant-pressure. Biotechnology Progress. Vol. In press, ISSN 1520-6033. 
Sierra, R., Garcia, L., Holtzapple, M. \& Laverde, D. (2011b). Selectivity and delignification kinetics for oxidative short-term lime pretreatment of poplar wood. Part II: varying pressure. Biotechnology Progress. Vol. In press, ISSN 1520-6033.

Sierra, R., Granda, C.B. \& Holtzapple, M. (2009a). Lime Pretreatment, In: Biofuels: Methods and Protocols, Mielenz, J. R., 115-124, Humana Press, ISBN 978-1-60761-213-1, New York.

Sierra, R., Granda, C.B. \& Holtzapple, M. (2009b). Short-Term Lime Pretreatment of Poplar Wood. Biotechnology Progress. Vol. 25, No. 2, (March 2009), pp. 323-332, ISSN 15206033.

Sierra, R., Holtzapple, M. \& Granda, C.B. (2010). Long-term Lime Pretreatment of Poplar Wood. AIChE Journal. Vol. 57, No. 5, (July 2010), pp. 1320-1328, ISSN 0001-1541.

Sierra, R., Smith, A., Granda, C.B. \& Holtzapple, M. (2008). Producing Fuels and Chemicals from Lignocellulosic Biomass. Chemical Engineering Progress. Vol. 104, No. 8, (August 2008), pp. S10-S18.

Silva, C.J.S.M. \& Roberto, I.C. (2001). Improvement of xylitol production by Candida guilliermondii FTI 20037 previously adapted to rice straw hemicellulosic hydrolysate. Letters in Applied Microbiology. Vol. 32, No. 4, (April 2001), pp. 248-252, ISSN 1472-765X.

Simmons, B.A., Loque, D. \& Blanch, H.W. (2008). Next-generation biomass feedstocks for biofuel production. Genome Biology. Vol. 9, No. 242, (December 2008), ISSN 14656914.

Simonne, A., Simonne, E., Eitenmiller, R., Mills, H. \& Cresman, C. (1997). Could the Dumas Method Replace the Kjeldahl Digestion for Nitrogen and Crude Protein Determinations in Foods? Journal of the Science of Food and Agriculture. Vol. 73, No. 1, (n.d.), pp. 39-45, ISSN 1097-0010.

Sinclair, R., Yamazaki, I., Bumpus, J., Brock, B., Chang, C.S., Albo, A. \& Powers, L. (1992). Structure of the active site of lignin peroxidase isozyme H2: native enzyme, compound III, and reduced form. Biochemistry. Vol. 31, No. 20, (May 1992), pp. 4892-900, ISSN 0006-2960.

Singh, P., Suman, A., Tiwari, P., Arya, N., Gaur, A. \& Shrivastava, A.K. (2008). Biological pretreatment of sugarcane trash for its conversion to fermentable sugars. World Journal of Microbiology and Biotechnology. Vol. 24, No. 5, (May 2008), pp. 667-673, ISSN 0959-3993.

Sjöström, E. (1981). The chemistry of oxygen delignification. Paperi ja puu. Vol. 63, No. 6-7, (n.d.), pp. 438-442, ISSN 0031-1243.

Sluiter, A., Hames, B., Ruiz, R., Scarlata, C., Sluiter, J. \& Templeton, D. (2004). Determination of Structural Carbohydrates and Lignin in Biomass. (1st edition), National Renewable Energy Laboratory, Golden, CO.

Sterjiades, R., Dean, J., Gamble, G., Himmelsbach, D. \& Eriksson, K. (1993). Extracellular laccases and peroxidases from sycamore maple (Acer pseudoplatanus) cellsuspension cultures - Reactions with monolignols and lignin model compounds. Planta. Vol. 190, No. 1, (May 1993), pp. 75-87, ISSN 0032-0935.

Sugiura, T., Yamagishi, K., Kimura, T., Nishida, T., Kawagishi, H. \& Hirai, H. (2009). Cloning and homologous expression of novel lignin peroxidase genes in the whiterot fungus Phanerochaete sordida YK-624. Bioscience, Biotechnology, and Biochemistry. Vol. 73, No. 8, (August 2009), pp. 1793-8, ISSN 1347-6947. 
Sun, Y. \& Cheng, J. (2002). Hydrolysis of lignocellulosic materials for ethanol production: a review. Bioresource Technology. Vol. 83, No. 1, (May 2002), pp. 1-11, ISSN 0960-8524.

Sundaramoorthy, M., Gold, M.H. \& Poulos, T.L. (2010). Ultrahigh (0.93A) resolution structure of manganese peroxidase from Phanerochaete chrysosporium: implications for the catalytic mechanism. Journal of Inorganic Biochemistry. Vol. 104, No. 6, (June 2010), pp. 683-90, ISSN 1873-3344.

Susilo, J. \& Bennington, C.P.J. (2007). Modelling Kappa Number and Pulp Viscosity in Industrial Oxygen Delignification Systems. Chemical Engineering Research and Design. Vol. 85, No. 6, (n.d.), pp. 872-881, ISSN 0263-8762.

Szczodrak, J. \& Fiedurek, J. (1996). Technology for conversion of lignocellulosic biomass to ethanol. Biomass and Bioenergy. Vol. 10, No. 5-6, (July 1996), pp. 367-375, ISSN 09619534.

Tamaki, Y. \& Mazza, G. (2010). Measurement of structural carbohydrates, lignins, and micro-components of straw and shives: Effects of extractives, particle size and crop species. Industrial Crops and Products. Vol. 31, No. 3, (May 2010), pp. 534-541, ISSN 0926-6690.

Tanksale, A., Beltramini, J.N. \& Lu, G.M. (2010). A review of catalytic hydrogen production processes from biomass. Renewable and Sustainable Energy Reviews. Vol. 14, No. 1, (January 2010), pp. 166-182, ISSN 1364-0321.

Templeton, D., Sluiter, A., Hayward, T., Hames, B. \& Thomas, S. (2009). Assessing corn stover composition and sources of variability via NIRS. Cellulose. Vol. 16, No. 4, (August 2009), pp. 621-639, ISSN 0969-0239.

Thring, R., Chornet, E. \& Qverend, R. (1990). Recovery of a solvolytic lignin: effects of spent liquor/acid volume ratio, acid concentration and temperature. Biomass. Vol. 23, (n.d), pp. 289-305, ISSN 0144-4565.

Timofeevski, S.L. \& Aust, S.D. (1997). Effects of Mn2+ and oxalate on the catalatic activity of manganese peroxidase. Biochemical and Biophysical Research Communications. Vol. 239, No. 3, (October 1997), pp. 645-9, ISSN 0006-291X.

Toivari, M.H., Salusjarvi, L., Ruohonen, L. \& Penttila, M. (2004). Endogenous Xylose Pathway in Saccharomyces cerevisiae. Applied and Environment Microbiology. Vol. 70, No. 6, (June 2004), pp. 3681-3686, ISSN 0099-2240.

Torgashov, V., Gert, E., Zubets, O. \& Kaputskii, F. (2010). A comparative study of isolation conditions, morphology, and properties of cellulose obtained from the stalks of cereals and oil-yielding plants. Russian Journal of Bioorganic Chemistry. Vol. 36, No. 7, (December 2010), pp. 838-846, ISSN 1068-1620.

Tripathi, M.K., Mishra, A.S., Misra, A.K., Vaithiyanathan, S., Prasad, R. \& Jakhmola, R.C. (2008). Selection of white-rot basidiomycetes for bioconversion of mustard (Brassica compestris) straw under solid-state fermentation into energy substrate for rumen micro-organism. Letters in Applied Microbiology. Vol. 46, No. 3, (March 2008), pp. 364-70, ISSN 1472-765X.

Turner, D., Xu, H., Cracknell, R.F., Natarajan, V. \& Chen, X. (2011). Combustion performance of bio-ethanol at various blend ratios in a gasoline direct injection engine. Fuel. Vol. 90, No. 5, (May 2011), pp. 1999-2006, ISSN 0016-2361.

Vasquez, M.P., da Silva, J.N., de Souza, M.B., Jr. \& Pereira, N., Jr. (2007). Enzymatic hydrolysis optimization to ethanol production by simultaneous saccharification 
and fermentation. Applied Biochemistry and Biotechnology. Vol. 137-140, No. 1-12, (April 2007), pp. 141-53, ISSN 1559-0291.

Vicuña, R. (2000). Ligninolysis. A very peculiar microbial process. Molecular Biotechnology. Vol. 14, No. 2, (February 2000), pp. 173-6, ISSN 1073-6085.

Vinuselvi, P., Park, J.M., Lee, J.M., Oh, K., Ghim, C.-M. \& Lee, S.K. (2011). Engineering microorganisms for biofuel production. Biofuels. Vol. 2, No. 2, (February 2011), pp. 153-166, ISSN 1759-7269.

Vries, S.C.d., Ven, G.W.J.v.d., Ittersum, M.K.v. \& Giller, K.E. (2010). Resource use efficiency and environmental performance of nine major biofuel crops, processed by firstgeneration conversion techniques. Biomass and Bioenergy. Vol. 34, (May 2010), pp. 588 - 601, ISSN 0961-9534.

Wan, C. \& Li, Y. (2010). Microbial delignification of corn stover by Ceriporiopsis subvermispora for improving cellulose digestibility. Enzyme and Microbial Technology. Vol. 47, No. 1-2, (July 2010), pp. 31-36, ISSN 0141-0229.

Wang, W. \& Wen, X. (2009). Expression of lignin peroxidase H2 from Phanerochaete chrysosporium by multi-copy recombinant Pichia strain. Journal of Environmental Sciences (China). Vol. 21, No. 2, (February 2009), pp. 218-22, ISSN 1001-0742.

Wang, Z.M., Bleakley, B.H., Crawford, D.L., Hertel, G. \& Rafii, F. (1990). Cloning and expression of a lignin peroxidase gene from Streptomyces viridosporus in Streptomyces lividans. Journal of Biotechnology. Vol. 13, No. 2-3, (February 1990), pp. 131-44, ISSN 0168-1656.

Wariishi, H., Valli, K. \& Gold, M.H. (1992). Manganese(II) oxidation by manganese peroxidase from the basidiomycete Phanerochaete chrysosporium. Kinetic mechanism and role of chelators. Journal of Biological Chemistry. Vol. 267, No. 33, (November 1992), pp. 23688-95, ISSN 0021-9258.

Whitwam, R.E., Brown, K.R., Musick, M., Natan, M.J. \& Tien, M. (1997). Mutagenesis of the Mn2+-binding site of manganese peroxidase affects oxidation of Mn2+ by both compound I and compound II. Biochemistry. Vol. 36, No. 32, (August 1997), pp. 9766-73, ISSN 0006-2960.

Wong, D.W. (2009). Structure and action mechanism of ligninolytic enzymes. Applied Biochemistry and Biotechnology. Vol. 157, No. 2, (May 2009), pp. 174-209, ISSN 15590291.

Wyman, C. \& Lloyd, T.A. (2005). Combined sugar yields for dilute sulfuric acid pretreatment of corn stover followed by enzymatic hydrolysis of the remaining solids Bioresource Technology. Vol. 96, No. 18, (December 2005), pp. 1967-1977, ISSN 0960-8524.

Wyman, C.E., Dale, B.E., Elander, R.T., Holtzapple, M., Ladisch, M.R. \& Lee, Y.Y. (2005a). Comparative sugar recovery data from laboratory scale application of leading pretreatment technologies to corn stover. Bioresource Technology. Vol. 96, No. 18, (December 2005), pp. 2026-2032, ISSN 0960-8524.

Wyman, C.E., Dale, B.E., Elander, R.T., Holtzapple, M., Ladisch, M.R. \& Lee, Y.Y. (2005b). Coordinated development of leading biomass pretreatment technologies. Bioresource Technology. Vol. 96, No. 18, (December 2005), pp. 1959-1966, ISSN 09608524.

Wyman, C.E., Dale, B.E., Elander, R.T., Holtzapple, M., Ladisch, M.R., Lee, Y.Y. \& Saddler, J.N. (2009). Comparative sugar recovery and fermentation data following 
pretreatment of poplar wood by leading technologies. Biotechnology Progress. Vol. 25, No. 2, (March 2009), pp. 333-339, ISSN 1520-6033.

Xiao, Y.Z., Hong, Y.Z., Li, J.F., Hang, J., Tong, P.G., Fang, W. \& Zhou, C.Z. (2006). Cloning of novel laccase isozyme genes from Trametes sp. AH28-2 and analyses of their differential expression. Applied Microbiology and Biotechnology. Vol. 71, No. 4, (July 2006), pp. 493-501, ISSN 0175-7598.

Yancey, M. \& Kadam, K. (1997). Biomass to ethanol facility design, cost estimate, and financial evaluation: Volume I. (1st ed.), National Renewable Energy Laboratory, Gorlden, CO.

Yu, H., Du, W., Zhang, J., Ma, F., Zhang, X. \& Zhong, W. (2010a). Fungal treatment of cornstalks enhances the delignification and xylan loss during mild alkaline pretreatment and enzymatic digestibility of glucan. Bioresource Technology. Vol. 101, No. 17, (September 2010), pp. 6728-34, ISSN 1873-2976.

Yu, H., Zhang, X., Song, L., Ke, J., Xu, C., Du, W. \& Zhang, J. (2010b). Evaluation of white-rot fungi-assisted alkaline/oxidative pretreatment of corn straw undergoing enzymatic hydrolysis by cellulase. Journal of Bioscience and Bioengineering. Vol. 110, No. 6, (December 2010), pp. 660-664, ISSN 1389-1723.

Yu, Q., Zhuang, X., Yuan, Z., Wang, Q., Qi, W., Wang, W., Zhang, Y., Xu, J. \& Xu, H. (2010c). Two-step liquid hot water pretreatment of Eucalyptus grandis to enhance sugar recovery and enzymatic digestibility of cellulose. Bioresource Technology. Vol. 101, No. 13, (July 2010), pp. 4895-4899, ISSN 0960-8524.

Yu, Y., Feng, Y., Xu, C., Liu, J. \& Li, D. (2011). Onsite bio-detoxification of steam-exploded corn stover for cellulosic ethanol production. Bioresource Technology. Vol. 102, No. 8, (January 2011), pp. 5123-5128, ISSN 0960-8524.

Zerbini, J.E., Oliveira, E.M. \& Bon, E.P. (1999). Lignin peroxidase production by Streptomyces viridosporus T7A: nitrogen nutrition optimization using glucose as carbon source. Applied Biochemistry and Biotechnology. Vol. 77-79, (March 1999), pp. 681-8, ISSN 0273-2289.

Zhang, G., Zhang, L., Deng, H. \& Sun, P. (2010). Preparation and characterization of sodium carboxymethyl cellulose from cotton stalk using microwave heating. Journal of Chemical Technology and Biotechnology. Vol. In press, (n.d.), ISSN 1097-4660.

Zhang, Y.H. (2008). Reviving the carbohydrate economy via multi-product lignocellulose biorefineries. Journal of Industrial Microbiology and Biotechnology. Vol. 35, No. 5, (May 2008), pp. 367-375, ISSN 1367-5435.

Zhao, X., Chen, K. \& Liu, D. (2009). Organosolv pretreatment of lignocellulosic biomass for enzymatic hydrolysis. Applied Microbiology and Biotechnology. Vol. 82, No. 5, (April 2009), pp. 815-827, ISSN 0175-7598.

Zhao, X., Zhang, L. \& Liu, D. (2008). Comparative study on chemical pretreatment methods for improving enzymatic digestibility of crofton weed stem. Bioresource Technology. Vol. 99, No. 9, (June 2008), pp. 3729-3736, ISSN 0960-8524.

Zhu, L., O'Dwyer, J.P., Chang, V.S., Granda, C.B. \& Holtzapple, M.T. (2008). Structural features affecting biomass enzymatic digestibility. Bioresource Technology. Vol. 99, No. 9, (June 2008), pp. 3817-3828, ISSN 0960-8524. 


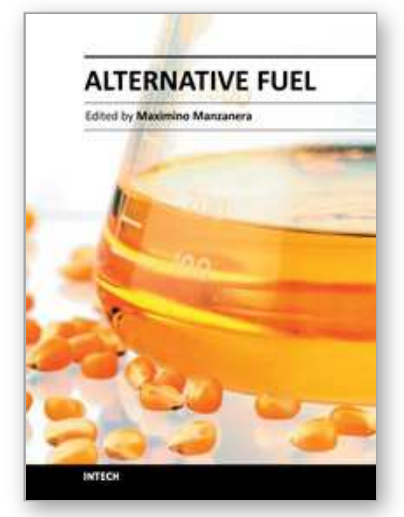

\author{
Alternative Fuel \\ Edited by Dr. Maximino Manzanera
}

ISBN 978-953-307-372-9

Hard cover, 346 pages

Publisher InTech

Published online 09, August, 2011

Published in print edition August, 2011

Renewable energy sources such as biodiesel, bioethanol, biomethane, biomass from wastes or hydrogen are subject of great interest in the current energy scene. These fuels contribute to the reduction of prices and dependence on fossil fuels. In addition, energy sources such as these could partially replace the use of what is considered as the major factor responsible for global warming and the main source of local environmental pollution. For these reasons they are known as alternative fuels. There is an urgent need to find and optimise the use of alternative fuels to provide a net energy gain, to be economically competitive and to be producible in large quantities without compromising food resources.

\title{
How to reference
}

In order to correctly reference this scholarly work, feel free to copy and paste the following:

Oscar Sánchez, Roció Sierra and Carlos J. Alméciga-Diaz (2011). Delignification Process of Agro-Industrial Wastes an Alternative to Obtain Fermentable Carbohydrates for Producing Fuel, Alternative Fuel, Dr. Maximino Manzanera (Ed.), ISBN: 978-953-307-372-9, InTech, Available from: http://www.intechopen.com/books/alternative-fuel/delignification-process-of-agro-industrial-wastes-analternative-to-obtain-fermentable-carbohydrates

\section{INTECH}

open science | open minds

\section{InTech Europe}

University Campus STeP Ri Slavka Krautzeka 83/A 51000 Rijeka, Croatia Phone: +385 (51) 770447 Fax: +385 (51) 686166 www.intechopen.com

\section{InTech China}

Unit 405, Office Block, Hotel Equatorial Shanghai No.65, Yan An Road (West), Shanghai, 200040, China 中国上海市延安西路65号上海国际贵都大饭店办公楼405单元 Phone: +86-21-62489820

Fax: $+86-21-62489821$ 
(C) 2011 The Author(s). Licensee IntechOpen. This chapter is distributed under the terms of the Creative Commons Attribution-NonCommercialShareAlike-3.0 License, which permits use, distribution and reproduction for non-commercial purposes, provided the original is properly cited and derivative works building on this content are distributed under the same license. 